\title{
Summary of the 2008 BTS/SIGN British Guideline on the Management of Asthma
}

\section{Mark L Levya, Mike Thomas ${ }^{b}$, lain R Smallc, Linda Pearced, Hilary Pinnocke, * Paul Stephenson ${ }^{f}$}

a Editor-in-Chief Primary Care Respiratory Journal; Senior Clinical Research Fellow, Allergy \& Respiratory Research Group, Division of Community Health Sciences: GP Section, University of Edinburgh, Scotland, UK

b Asthma UK Senior Research Fellow, Department of General Practice and Primary Care, University of Aberdeen, Scotland, UK; General Practitioner, M inchinhampton Surgery, Gloucestershire, UK

c Chairman, General Committee, UK General Practice Airways Group; General Practitioner, Peterhead Health Centre, Peterhead, Scotland, UK

d Nurse Consultant, Department of Respiratory M edicine, West Suffolk Hospital, Bury St Edmunds, Suffolk, UK

e Clinical Research Fellow, Allergy \& Respiratory Research Group, Division of Community Health Sciences: GP Section, University of Edinburgh; General Practitioner, Whitstable Medical Practice, Whitstable, Kent, UK

f Deputy Editor and Supplements Editor, Primary Care Respiratory Journal; General Practitioner, The Christmas Maltings and Clements Practice, Haverhill, Suffolk

Received 10th June 2008; revised version received 20th July 2008; accepted 21st August 2008

\section{Summary}

The 2008 BTS/SIGN British Guideline on the management of asthma provides comprehensive updated evidence-based guidance on asthma management for healthcare professionals. This primary care-focussed summary has been produced to aid dissemination and implementation of the key guideline messages into primary care. The section on diagnosis emphasises the new integrated symptombased approach with clinicians using their deductive skills to determine the probability that the patient has asthma. The various tools used for monitoring asthma are discussed. There are sections on both non-pharmacological and pharmacological management of chronic asthma in adults and children. Treatment options for children are subbdivided into the under-5s and children aged 5-12 years. Poor asthma control is manifested by exacerbations and acute asthma. Personalised asthma action plans for guided self management should be provided and used when levels of asthma control change. There are sections on difficult asthma and the treatment of exacerbations and acute severe asthma. Various outcome measures for auditing the quality of asthma care are discussed.

c 2008 General Practice Airways Group. All rights reserved.

ML Levy, et al. Prim Care Resp J 2009; 18(Suppl 1): S1-S16.

doi:10.3132/pcrj.2008.00067

Keyw ords: asthma, guideline, UK, BTS/SIGN, diagnosis, management, treatment, adults, children, chronic, acute, control, audit, outcomes, quality of care

\section{Contents}

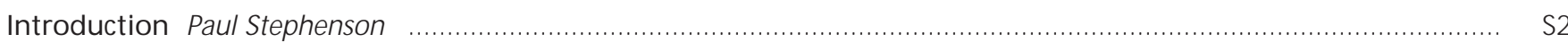

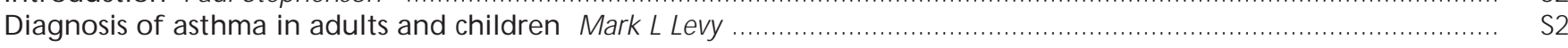

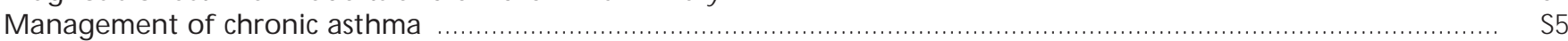

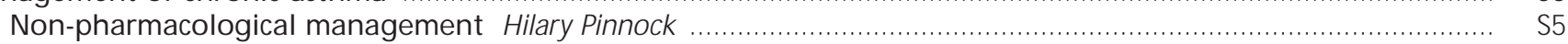

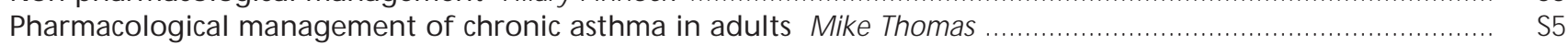

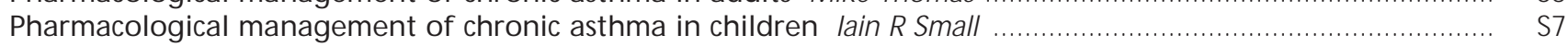

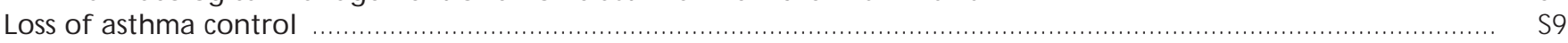

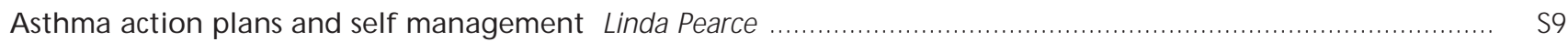

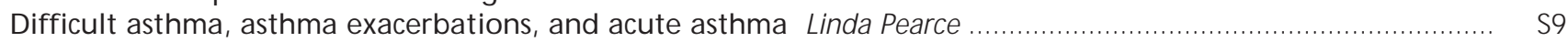

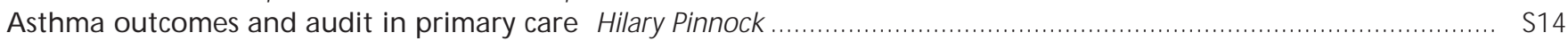

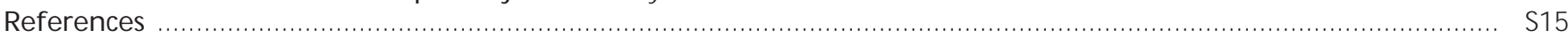

\footnotetext{
* Corresponding author: c/o GPIAG, Smithy House, Waterbeck, Lockerbie, DG11 3EY, UK

Tel: +44 (0)1461 600639 Fax: +44 (0)1461 207819 E-mail: paul.stephenson@gp-d83012.nhs.uk
} 


\section{Introduction}

\section{Paul Stephenson}

The 2008 British Guideline on the management of asthma from the British Thoracic Society (BTS) and the Scottish Intercollegiate Guidelines Network (SIGN), published in Thorax, ${ }^{1}$ provides updated, comprehensive, evidence-based guidance on asthma management for all healthcare professionals.

The first collaborative BTS/SIGN guideline was published in 2003. The 2008 guideline references literature published up to $M$ arch 2007, and contains a completely rewritten section on the diagnosis of asthma as well as updated sections throughout. As before, levels of evidence in the new guideline range from Level $1^{++}$(high quality meta-analyses, systematic reviews of randomised controlled trials (RCTs), or RCTs with a very low risk of bias) to Level 4 (expert opinion). Grading of recommendations ranges from Grade A (at least one meta-analysis, systematic review, or RCT rated as $1^{++}$) to Grade D (evidence level 3 or 4 , or extrapolated evidence from studies rated as $2^{+}$).

The BTS and SIGN have worked in collaboration with many other UK professional bodies, including the General Practice Airways Group (GPIAG), to develop the 2008 guideline. The development process and methodology has been systematic, rigorous and extensive - clear evidence of dedicated input by the Executive and Steering Group, the contributing committees, authors and reviewers.

However, whatever the nature of guidelines - be they national, ${ }_{1}^{1}$ global, ${ }^{2}$ disease-specific, ${ }^{1-3}$ integrated, ${ }^{3-6}$ primary carebased $^{3.6}$ intended for resource-rich ${ }^{1,2,3,5}$ or for resource-poor ${ }^{3-6}$ settings - dissemination and implementation is the crucial step. ${ }^{1,2,4,7,8}$ In most countries, primary care clinicians treat the vast majority of patients with asthma and other chronic respiratory diseases. ${ }^{9,10}$ The GPIAG has been represented on many of the 2008 BTS/SIGN guideline working groups - including the dissemination group - and has liaised closely with the BTS/SIGN Executive regarding dissemination and implementation of the key guideline messages into primary care. This summary should therefore be invaluable to all GPs and primary care respiratory nurses in implementing the 2008 guideline.

\section{Diagnosis of asthma in adults and children} Mark L Levy

Diagnosis in primary care

The first step of management is to establish the diagnosis. Given the nature of primary care, with fairly short consultations during which patients can present multiple unrelated and undiagnosed symptoms, GPs often have to consider numerous differential diagnoses. What complicates matters is the many other tasks to be performed during the consultation. However, in primary care there is always the possibility of a series of consultations over time which can help develop and refine the diagnostic process.

An integrated approach to diagnosis

The $2008 \mathrm{BTS} / \mathrm{SIGN}$ guideline approach to diagnosis ${ }^{1}$ is based on the primary care model, focussing on the patient's presenting symptoms and then developing the theory and detail required to achieve an accurate diagnosis - an integrated approach adopted previously by the International Primary Care Respiratory Group (IPCRG). ${ }^{4,5}$ The diagnosis of asthma is based on the clinical history and subsequent findings, complicated further by the absence of standardised diagnostic tests; " there is no standardised definition of the type, severity or frequency of symptoms, nor of the findings on investigation". ${ }^{1}$ The guideline therefore encourages clinicians to use their knowledge and deductive skills to determine the 'probability' of someone having asthma when they present with symptoms.

Principles underlying assessment of asthma control

These diagnostic principles also underpin the assessment of asthma control. Tools and instruments included in the diagnosis section of the 2008 guideline (as is also the case with the GINA guideline ${ }^{2}$ ) can be used to assess asthma control; this is an area of considerable research interest. ${ }^{11}$ Furthermore, there has been considerable interest in the literature on providing patients with information on the levels of control they can expect from their management, since many patients are resigned to the effects of poor asthma control. ${ }^{12}$

Assessing the probability of a diagnosis of asthma Accuracy is clearlyessential and this explains the focus of the new diagnostic approach: "wherever possible, try to obtain objective confirmation of the diagnosis". ${ }^{2}$ Thus, the guideline encourages clinicians to refine their diagnostic hypothesis by weighing up the features that influence the probability of asthma. This novel pragmatic approach differs from the traditional advice that clinicians should rigidly diagnose asthma according to set parameters.

After initial assessment and consideration of the patient's history, physical examination and investigations, three levels of diagnostic probability are recommended in adults and children. Subsequent treatment and investigations are then based on the likelihood of asthma.

The three levels are:

- High probability - diagnosis of asthma likely

- Intermediate probability - diagnosis uncertain

- Low probability - diagnosis other than asthma likely

The approach in children and adults differs in some respects. These are summarised in Figures 1 and 2 .

For clinicians to use this process in practice, a working knowledge of the information in Tables 1-5 helps in understanding the clinical, epidemiological features, and other factors which can determine the level of probability that the patient has asthma. Where these differ for adults and children, this is indicated.

One of the commonest questions asked by parents is, "W ill my child grow out of their asthma?" Possible responses and the theory underlying these are provided in Table 3.

In adults and children with a high probability of asthma the 2008 guideline advises treatment and (most importantly) follow-up review to assess the response and level of control - i.e. the use of treatment as a diagnostic tool. 
Figure 1: Flow diagram showing the diagnostic process in children in relation to the initial clinical assessment and probability of asthma [reproduced with permission].

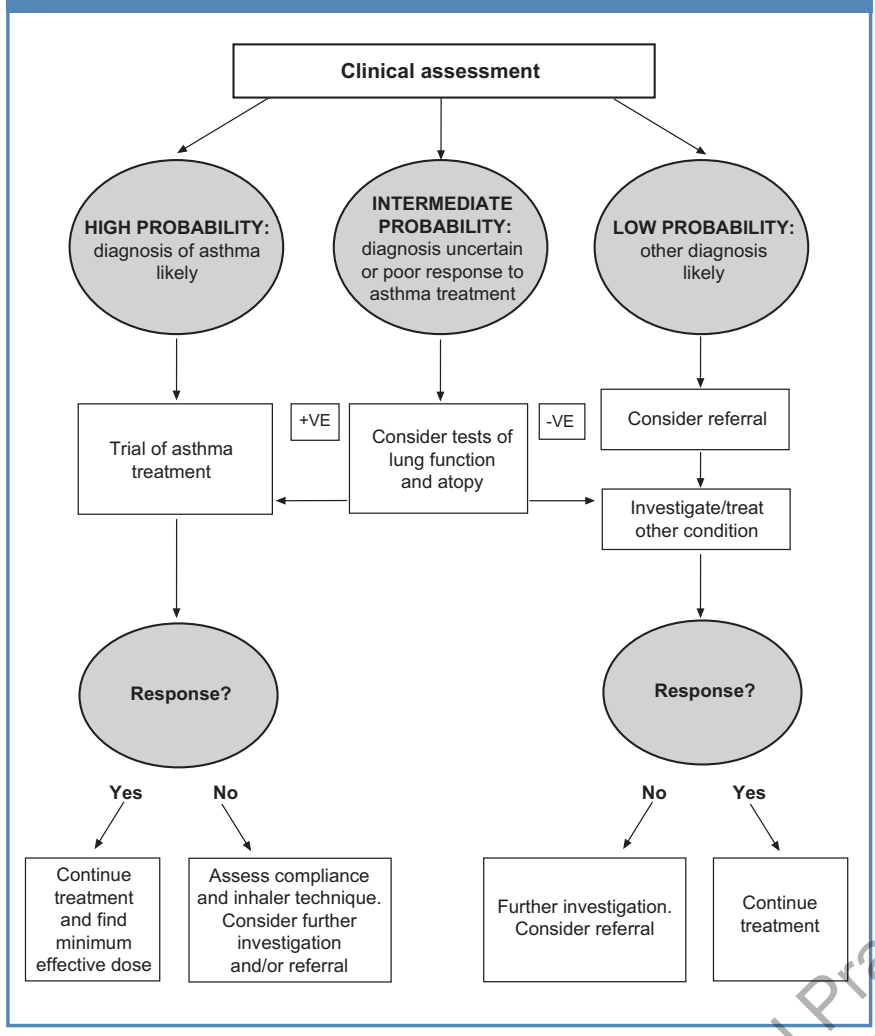

In those with a low probability of asthma other diagnoses should be considered carefully. In children, particularly those aged under five, consider cystic fibrosis, congenital disorders, gastro-oesophageal reflux and bronchiectasis; referral to a respiratory specialist is advised. ${ }^{13}$ In adults, the main differential diagnoses are cardiovascular, gastrointestinal, hyperventilation, vocal cord dysfunction, COPD, bronchjectasis, and lung cancer.

In children and adults with anintermediate probability of asthma, watchful waiting with follow-up is advised, with or without a trial of treatment, all depending on the severity of symptoms. In those patients with an intermediate or low probability of asthma, or those with a high probability who do not respond to therapy, further investigations and specialist referral may be indicated.

Occupational asthma

Only a minority of the estimated $15 \%$ of adults with an occupational cause for their asthma are recognised, and primary care clinicians should consider the possibility of occupational asthma especially in patients in high risk occupations such as paint spraying, industrial baking, nursing, welding and in timber workers. Any adult with late onset asthma or recurrence of childhood symptoms should be asked if their symptoms improve when away from work - asking about symptoms solely at work will overlook patients whose occupational asthma develops after some hours' delay. The best screening questions are:
Figure 2: Flow diagram showing the diagnostic process in adults in relation to the initial clinical assessment and probability of asthma [reproduced with permission].

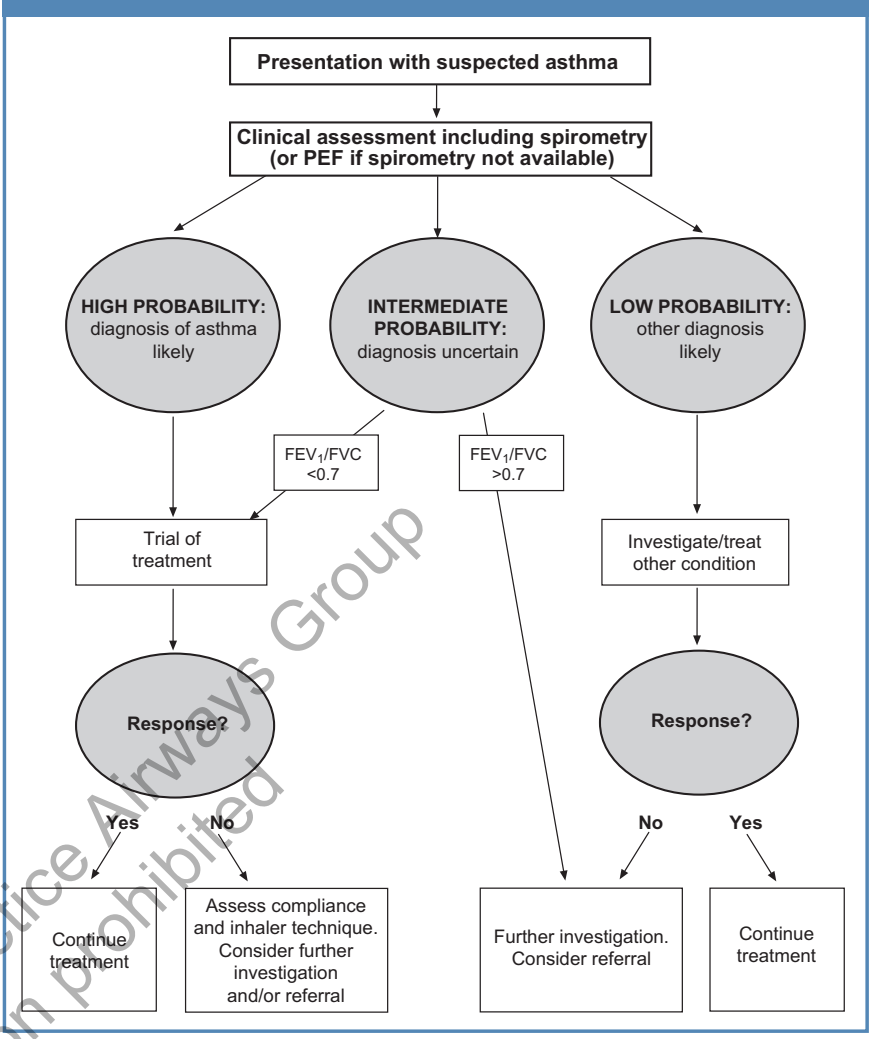

\section{Table 1: Clinical features that increase the probability of asthma in children [reproduced with permission].}

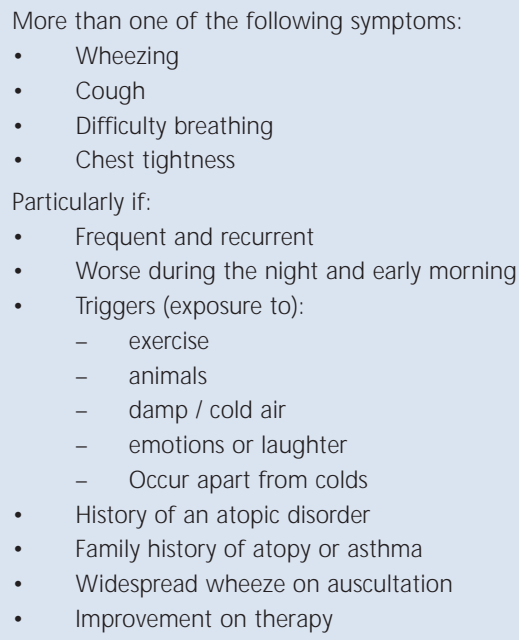

"Are you better on days away from work?"

"Are you better on holiday?"

These questions are non-specific, but positive answers indicate the possibility of occupational asthma. If so, significant peak expiratory flow (PEF) variability on a 4-hourly chart (both at work and away from work) will assist in establishing the diagnosis. 
ML Levy et al.

\section{Table 2 : Clinical features that lower the probability of asthma in children [reproduced with permission].}

- $\quad$ Symptoms with colds only - no interval symptoms

- Isolated cough - no wheezing

- Moist cough

- Dizziness, light headedness, peripheral tingling

- Repeated normal chest examination when symptomatic

- $\quad$ Normal lung function (PEF/Spirometry) when symptomatic

- No response to a trial of asthma therapy

Table 3 : Factors that are associated with a high or low risk of developing persisting wheeze or asthma through childhood [reproduced with permission].

- Age: the earlier the onset of wheeze, the better the prognosis. Most children presenting under two years of age will 'grow out' of their asthma

- $\quad$ Gender: boys are more likely to suffer from pre-pubertal asthma than girls; they are also more likely to grow out of wheezing during adolescence than girls

- $\quad$ Severity: frequent severe wheezing - usually persists

- Positive tests for atopy increase the likelihood of developing asthma, these include:-

Positive skin prick tests in wheezy children

Specific lgE to wheat, egg white, House Dust Mite and cat

A raised eosinophil count

- Co-existent atopy and illnesses like rhinitis and eczema increases the risk of developing asthma which is independent of age

- Family history of atopy: one of the strongest predictors or risk factors for children developing asthma, particularly if the mother is atopic

- Abnormal lung function and increased airway hyper-responsiveness in childhood are both associated with asthma in later life?

Specialist assessment for patients with Suspected occupational asthma is mandatory. ${ }^{1,2,14-18}$

Further diagnostic investigations

Lung function: Normal lung function in asymptomatic patients does NOT necessarily rule out a diagnosis of asthma. Determining the variability of airflow limitation is important, since it is key to both the initial asthma diagnosis and recognition of poor asthma control which requires intervention.

- In older children and adults, the variability of lung function measurements combined with trials of treatment may help increase the probability of asthma diagnosis.

- Spirometry: An improvement in forced expiratory volume in one second $\left(\mathrm{FEV}_{1}\right)$ of over $12 \%$ from baseline in children, and over $400 \mathrm{ml}$ in adults, indicates reversible airflow obstruction and supports the diagnosis of asthma.

- Peak expiratory flow: No data is available for acceptable levels of variability of PEF in children. Therefore clinicians need to make a clinical judgement on the significance of PEF change from baseline or after bronchodilators. In adults, asthma is likely if the PEF variability is over $20 \%$ and $8 \%$ in the case of four or two readings a day, respectively. Therefore, a chart with
Table 4: Clinical features that increase the probability of asthma in adults [reproduced with permission].

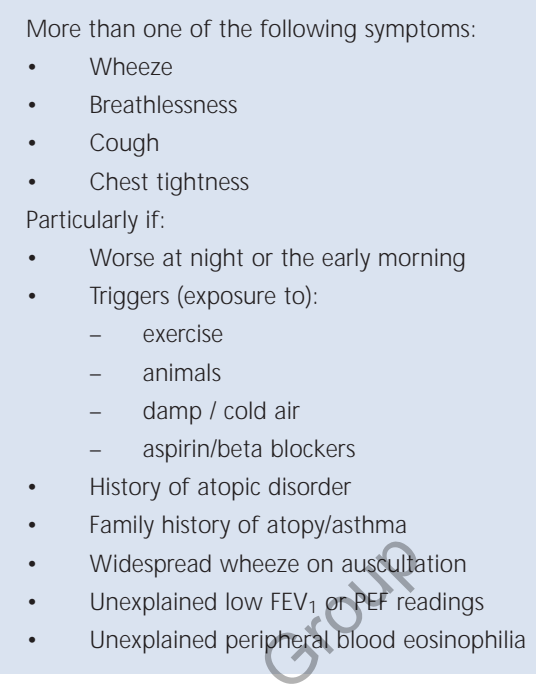
c)

Table 5: Feakyres that lower the probability of asthma in adults [reproduced with permission].

- Chronic productive cough in the absence of wheeze/breathlessness Dizziness, light headedness, peripheral tingling

Repeated normal chest exam when symptomatic

Repe

- Normal lung function (PEF/spirometry) when symptomatic

Voice disturbance

Symptoms with URTIs only

$>20$ pack years smoking

- Cardiac disease

- Normal lung function when symptomatic

two readings a day, showing variability over $8 \%$, strongly implies asthma in adults with a suggestive history. ${ }^{1}$

- Allergy tests: Positive skin tests, blood eosinophilia (>4\% ) and raised slgE to cat, dog or house dust mite, increase the probability of asthma in a child over five years with wheeze.

- Chest X-rays are indicated in adults and children with severe disease or clues to other conditions than asthma. ${ }^{1,5}$

- Tests of airway hyper-responsiveness, including challenge tests, eosinophilic airway inflammation, induced sputum differential eosinophil count, or the fraction of exhaled nitric oxide (FeNO), are currently outside the domain of primary care, apart from a few specialised general practices. ${ }^{19}$ Specialist referral is required if these tests are needed.

- Exercise testing in children, where significant reduction in PEF before and after six minutes of running may help increase the likelihood that a patient has asthma.

\section{Monitoring asthma}

The new guideline has included monitoring in the diagnosis section. ${ }^{1}$ Monitoring facilitates the diagnostic process by determining patients' response to treatment, reinforcing or reducing the probability of asthma, while also providing clinicians 
and patients with information to underpin treatment and/or referral decisions. Various tools, some validated, are listed, together with their indications, interpretation and sources, most with the aim of reducing underestimation of patients' symptoms or levels of control ${ }^{1,20,21}$ (Box 1). These include composite symptom and quality of life scores, lung function tests, exacerbations, inhaler technique and compliance assessment systems. Clinicians are advised to use some of these in day-to-day practice, ${ }^{1}$ particularly the composite symptom questionnaires such as the (as yet unvalidated) RCP 3 questions ${ }^{22}$ (see Box 2) and the Asthma Control Test (ACT) questionnaire.

\section{Management of chronic asthma Non-pharmacological management}

Hilary Pinnock

Allergen avoidance and dietary supplements

Primary care clinicians are familiar with requests for advice on allergen avoidance, dietary measures and supplements that patients hope will improve their asthma. However, the 2008 BTS/SIGN guideline assesses most of the popular nonpharmacological interventions as 'unproven' because of the limited evidence base. ${ }^{1}$ There are two main exceptions: smoking is associated with wheezing in infancy and persistent asthma in adult life, so that smoking cessation not only benefits the smoker but also reduces the impact of passive smoking on members of the family; and weight reduction has been shown to improve asthma symptoms in obese patients. The only other intervention with sufficient evidence to support a Grade C recommendation is. breast feeding for at least four months which, apart from generaf health benefits, may protect against early onset of asthma.

House dust mite (HDM) allergen is a recognised trigger for asthma symptoms, but reducing levels of HDM alone does not confer measurable improvement in asthma confrol. Patients should be aware of this before they embark on complex, and often expensive, avoidance strategies. ${ }^{23-25}$ Similarly, dietary manipulation (e.g. supplements of magnesium, selenium, fish oils, anti-oxidants, probiotics) are of unproven value. ${ }^{1}$

Complementary therapies

The Buteyko breathing technique controls hyperventilation and reduces asthma symptoms, but with no effect on lung function. ${ }^{1}$ Yoga can reduce bronchial hyperreactivity. ${ }^{1}$ There is no evidence to support acupuncture, ionisers, homeopathy or Chinese herbal therapies.

Occupational asthma

A diagnosis of occupational asthma has significant implications for the patient, and GPs may have an important supportive role. Prompt removal from the allergen is critical since prolonged exposure worsens the prognosis.1,14.18 Employers have a legal obligation to 'prevent or adequately control exposure' to respiratory allergens, and the Health and Safety Executive provides advice on suitable strategies; ${ }^{26}$ but in reality a third of patients with occupational asthma face unemployment or loss of income. ${ }^{14-18,27}$ Information about Industrial Injuries Disablement Benefit is available from the benefits agency.

\section{Box 1. Tools used to assess and measure asthma control ${ }^{1}$}

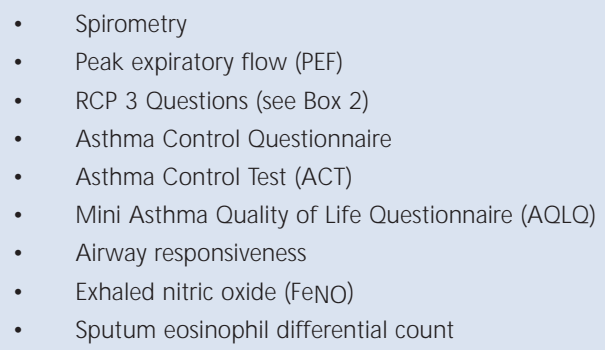

\section{Box 2. RCP 3 questions ${ }^{22}$}

In the last week (or month):

- Have you had difficulty sleeping because of your asthma symptoms (including cough?)

- Have you had your usual asthma symptoms during the day (cough, wheeze, chest tightness or breathlessness)?

- Has your asthma interfered with your usual activities (e.g. housework, work/school etc)?

\section{Pharmacological management of chronic asthma in adults}

Mike Thomas

The aims of chronic asthma management

Guidance on the pharmacological management of chronic asthma Occupies a central position in the $2008 \mathrm{BTS} / \mathrm{SIGN}$ guideline. ${ }^{1}$ The aim of asthma management is to achieve a very high level of disease control (see Box 3) with minimum side effects. 'High' control is now defined as no symptoms and no need for rescue medication, as opposed to the 'minimal' levels permitted in the 2003 guideline. There is new emphasis on recognising that each patient will have different personal goals for their asthma management and that some individuals wish to balance perfect control against the potential side effects or inconvenience of taking medication needed to achieve and maintain this. The focus on patient-set targets recognises the need for dialogue with patients to achieve a workable partnership, recognising their needs and preferences as well as the ideal of perfect control. This should result in better-informed patients who are able to make rational decisions ${ }^{12}$ - thereby reducing poor adherence with regular preventer therapy ${ }^{28}$ and poor outcomes. ${ }^{29,30}$

\section{Stepwise therapy}

The familiar stepwise approach is maintained (Figure 3), although there are a number of important changes and shifts in emphasis. The aim of pharmacological treatment remains to achieve and maintain control by stepping up or down as appropriate. As with the international GINA guideline, ${ }^{2}$ the level of treatment is dictated by an assessment of control rather than by an assessment of 'severity' (which is difficult to assess in treated patients). The need to check adherence, inhaler technique and trigger factor exposure before initiating new drug therapy is stressed. 
ML Levy et al.

In summary, all patients should be prescribed short-acting $\beta_{2}$-agonists (SABAs) for 'as required' short term reliever therapy (Step 1, mild intermittent asthma), and low to moderate dose inhaled corticosteroids (ICS) should be initiated in those with persistent symptoms (Step 2, regular preventer therapy). Add-on therapy with a trial of an inhaled long-acting $\beta_{2}$-agonist (LABA) as the first choice option should be commenced if the patient is still uncontrolled (Step 3, initial addon), with trials of other add-on medication and higher dose ICS at Step 4 (persistent poor control). Maintenance oral steroid treatment (Step 5) should only be used under specialist supervision.

There is greater focus on 'stepping dow $n$ ' treatment, with an equally prominent 'downwards' arrow in Figure 3 advising the clinician to 'move down to find and maintain the lowest controlling step'. M any patients on higher dose ICS can have their dose reduced without loss of asthma control. ${ }^{31}$ Stepping down (reductions in medication) can be considered in patients who have been stable for three months, by reducing the ICS dose (25-50\% reduction each time) or by discontinuing add-on therapy.

More detailed advice on when to 'step up' is also provided in the 2008 guideline, in particular, when to start treatment with ICS (Box 4); a patient needing to use rescue short-acting bronchodilators more than three times a week should be regarded as uncontrolled and ICS should be added. Any patient using more than two SABA inhalers per month on $>10$ puffs per day is at high risk (including risk of fatal or near-fatal asthma) and in need of urgent attention. ${ }^{1}$

Regular preventer therapy: Step 2

Inhaled steroids (ICS) remain the treatment of choice for persistent asthma. Other than ciclesonide, which may be given as once-daily dosage, ICS should be given in twice-daily doses, although oncedaily dosing may be considered in mild stable cases. ${ }^{32}$ The starting dose of ICS will usually be $400 \mathrm{mcg} /$ day for CFC-containing beclometasone (BDP) and budesonide preparations, and $200 \mathrm{mcg} /$ day for fluticasone, mometasone and ultra-fine CFC-free beclometasone preparations (due to their greater potency or higher lung deposition). The potency equivalence for ciclesonide is not established, although evidence suggests lower systemic and local side effects. ${ }^{33}$ Whether different types of ICS are safer or more effective is not clear from current evidence.

Higher ICS doses can be used as initial treatment in more severe asthma, although previous advice to start 'very high' and step down has been shown to confer no benefit and should be abandoned. ${ }^{1}$ However, it has become clear from recent evidence that people with asthma who smoke get less effect from ICS, and higher doses (e.g. $>1000 \mathrm{mcg} /$ day) may be needed due to the patient's smoking-related steroid resistance. Every effort should be made to stop asthmatic patients smoking.

The guideline contains an expanded section considering the safety profile of ICS: at doses below $800 \mathrm{mcg} /$ day (BDP equivalent) there is little evidence of local or clinically significant systemic side effects other than dysphonia and oral candidiasis. ${ }^{1}$ Some patients will be using other topical steroids (e.g. skin and nasal preparations) and the total steroid load should be considered and kept as low as is consistent with therapeutic effectiveness.

Previous advice to double the dose of ICS at the time of an exacerbation has been invalidated, ${ }^{1}$ although there is some evidence that a five-fold increase may be of use in adults on a low dose (200mcg/day BDP equivalent) of ICS. ${ }^{34}$ However, the new guideline states that this policy should not be extrapolated to patients already taking higher doses of ICS and that further evidence is needed.

Step 3: Initial add-on

A trial of a long-acting $\beta_{2}$-agonist (LABA) remains the add-on treatment of choice for patients whose asthma remains uncontrolled on ICS alone; LABAs should never be used without ICS in asthma due to safety concerns follow ing prospective and anecdotal studies which showed an increase in asthmatic patients using LABAs alone. ${ }^{35,36}$ However, there is no evidence of any increased risk when a LABA is used in conjunction with ICS for asthma. ${ }^{37}$

The level at which add-on therapy should begin cannot be defined completely, but all adults given a LABA should be on at least $200 \mathrm{mcg}$ of BDP-equivalent ICS a day, and no patient should be on $>800$ mcg ICS without a prior trial of a LABA. Although the 
overall effect of treating with both ICS and LABA is the same when the ICS and LABA are given by separate or ICS/LABA combination inhalers ${ }^{1,2}$ there is a strong argument (endorsed by NICE) for giving these drugs as a combination ICS/LABA combination inhaler which ensures that the LABA cannot be taken without the ICS. ${ }^{1,2}$

The new guideline emphasises the need to strive for high levels of asthma control, with no breakthrough symptoms or exacerbations. A study in which the aim was to obtain 'total control' in patients using varying strengths of the fluticasone/salmeterol combination inhaler showed that significantly more patients obtained guideline-defined control ${ }^{2}$ more rapidly, and at a lower total dose of ICS, compared to using fluticasone alone. ${ }^{38,39}$

The combination budesonide/formoterol inhaler can be used as rescue medication (instead of a SABA) in addition to its use as regular maintenance controller therapy (Single inhaler Maintenance And Reliever Therapy - the 'SMART' regime) in adult patients (aged 18 years and over) at Step 3 who are poorly controlled. There is considerable evidence showing this to be an effective $^{2,40,41}$ and cost-effective ${ }^{42}$ treatment option. The SMART regime has not yet been investigated with other combination inhalers, and requires careful patient education.

Not all patients respond in the same way to a given therapy, and the guideline recognises that some patients may not respond to a LABA; in which case the LABA should be stopped, and if patients remain uncontrolled on $800 \mathrm{mcg} /$ day of BDP-equivalent ICS, other add-on options can be tried - such as leukotriene receptor antagonists (LTRAs) or theophylline; LTRAs may be a. good option in patients with exercise-induced asthma and in patients with co-morbid allergic rhinitis. ${ }^{1}$

Steps 4 and 5: Severe asthma

A small number of patients may require higher doses of ICS or multiple add-on therapies. New treatments include anti-TNF alpha therapy (for which evidence is currently inadequate to recommend its use outside clinical trials) and anti-lgE monoclonal antibody (omalizumab) which reduces the (evels of free lgE. Omalizumab is now licensed for patients on high dose ICS and LABA who have an allergic trigger, raised IgE level, and who remain uncontrolled but it should only be used under specialist supervision.

Managing asthma in pregnancy

Asthma treatment is safe in pregnancy and the aim is to maintain good asthma control. ${ }^{1}$ The risk of harm to the fetus from severe or chronically-undertreated asthma outweighs any possible small risk from SABAs, ICS, LABAs, LTRAs and theophyllines, though LTRAs should not be commenced for the first time during pregnancy. ${ }^{1}$ About a third of pregnant women will experience an improvement in their asthma, a third will be worse, and a third will remain the same.

\section{Pharmacological management of chronic asthma in children}

lain R Small

Managing different age groups

When addressing the needs of children with asthma, there are

\section{Box 3. Aims of asthma management. ${ }^{1}$}

- No daytime symptoms
- No night-time awakening due to asthma
- No exacerbations
- No limitations on activities including exercise
- Normal lung function (FEV 1 and/or PEF $>80 \%$ predicted or best)
No side effects

\section{Box 4. Criteria for starting regular ICS preventer therapy. ${ }^{1}$}

$$
\begin{aligned}
& \text { - Any exacerbation of asthma in the last two years (Evidence grade B) } \\
& \text { - } \quad \text { Use of SABA three times a week or more (Evidence grade B) } \\
& \text { - } \quad \text { Waking one night a week (Evidence grade B) }
\end{aligned}
$$

clearly different problems and different treatment options when managing a two-year old and a 12-year old.

The 2008 guideline therefore refers to two age groups, 'children under 5 years', and 'children aged 5-12 years', although in some situations the guidance is the same. Over the age of 12 yearsadult guidance applies - although it should be noted that some treatments and strategies (such as SM ART) do not apply under the age of 18 years. ${ }^{1,2}$

Gaining control

The emphasis for patients and clinicians is on gaining asthma control. The definition of good asthma control is the same in children as in adults (see Box 3), with the proviso that lung function measurements cannot be used reliably to monitor or guide asthma management in children under 5 years.

A stepwise approach (see Table 6)

In younger children, the early abolition of symptoms will guide treatment choices. In older children ( $>5$ years), PEF monitoring can also be used to assess control. Although this stepwise method is very familiar, children should start treatment on the step most appropriate to their presenting level of symptoms and severity, within the licensed recommendation of the therapies being considered, aiming to achieve early symptom control. The clinician should be willing to begin at any treatment step - to step up if control is not achieved, and to step down once good control is established. ${ }^{1}$

There is no evidence to support the use of ICS in the treatment of viral-induced wheeze in infancy, for whom a 'watch and wait' policy should be pursued wherever possible. ${ }^{1,13}$

In all age groups, the presence of any one of the following factors indicating poor asthma control should prompt reassessment;

- using inhaled $\beta_{2}$-agonists three times a week or more;

- being symptomatic three times a week or more

- waking one night a week due to symptoms

In addition to using these three indictors of poor asthma control, in children aged 5-12 years an exacerbation requiring 
ML Levy et al.

oral steroids in the previous two years is also a sign of poor asthma control.

\section{Exercise-induced asthma}

Exercise-induced symptoms are a reflection of poorly controlled asthma and should be dealt with as such. True exercise-induced asthma (which is rare) should be managed with SABAs, preferably used before exercise.

In all circumstances, the following should be checked before therapy is changed;

- adherence with existing therapy

- inhaler technique

- elimination (where possible) of trigger factors

Doses and devices

Although CFC-containing BDP is being phased out, it remains the standard dose equivalent for all ICS preparations. The comparable dose of other ICS must be calculated, taking particular care with more potent drugs.

No inhaler device should be prescribed without effective training, assessment and regular review of technique. There is no evidence to support nebulised therapy in younger children as opposed to a pressurised metered-dose inhaler (pMDI) and spacer (with a mask in younger children). In children under five years, this is the preferred delivery method for treating exacerbations.

In 5-12 year olds, there is evidence of similar efficacy for pMDI/spacer and dry powder inhalers (DPIs). ${ }^{1}$

Safety and efficacy

Short-acting bronchodilators

In both age groups, SABAs are safe and effective. There is no evidence that regular use is more effective than 'as required' use; the latter should be recommended to patients and parents.

In children under 5 years, ipratropium bromide is also a safe and effective bronchodilator.

Inhaled corticosteroids (ICS)

Advice on ICS can be divided into three categories:

- Daily doses of 400mcg (BDP equivalent) or less

ICS are the most effective 'preventer' drug for achieving asthma control in older children. At recommended doses (see Table 6), they are safe and effective, even in infants and young children with asthma.

- Daily doses between 400-800mcg (BDP equivalent)

Above $400 \mathrm{mcg} /$ day there is evidence of systemic side effects such as growth failure and adrenal suppression. Additional treatments should be introduced, keeping the ICS dose at or below $400 \mathrm{mcg}$ where possible.

Children should have their height measured as part of their regular asthma review, though this cannot be used as a proxy indicator for adrenal function.

- Daily doses greater than 800mcg (BDP equivalent)

Adrenal insufficiency of clinical significance has been shown to occur at ICS doses of $800 \mathrm{mcg}$ and above in children. When children require such dosages;

- Specific written advice about steroid replacement during illness
Table 6. Recommended treatment steps for children ${ }^{1}$

\begin{tabular}{|c|c|c|}
\hline STEP & Under 5 years & $5-12$ years \\
\hline $\begin{array}{l}\text { Mild } \\
\text { Intermittent }\end{array}$ & $\begin{array}{l}\text { Inhaled short-acting } \beta_{2} \text {-agonist. } \\
\text { Inhaled ipratropium bromide. }\end{array}$ & hort-acting $\beta_{2}$-agonist. \\
\hline Step 2 & $\begin{array}{l}\text { Inhaled corticosteroids, } \\
200-400 \text { mcg BDP or } \\
\text { equivalent. Or, if ICS are not } \\
\text { suitable, LTRA }\end{array}$ & $\begin{array}{l}\text { Inhaled corticosteroid } \\
200-400 \mathrm{mcg} \text { BDP or } \\
\text { equivalent. }\end{array}$ \\
\hline Step 3 & $\begin{array}{l}\text { If on ICS, add LTRA. If on } \\
\text { LRTA, add ICS } 200-400 \mathrm{mcg} \\
\text { BDP/equivalent. In children } \\
<4 \text { yrs, refer for Paediatric } \\
\text { opinion. }\end{array}$ & $\begin{array}{l}\text { Add inhaled LABA } \\
\text { - If effective, continue. } \\
\text { - If partially effective, continue } \\
\text { LABA and increase ICS to } \\
400 \mathrm{mcg} \text { BDP. } \\
\text { - If ineffective, stop LABA and } \\
\text { increase ICS to } 400 \mathrm{mcg} \text { BDP. } \\
\text { Consider Add-on therapy } \\
\text { - LTRA } \\
\text { - (Theophylline } \\
\text { - Nedocromil) }\end{array}$ \\
\hline & Il children for & $\begin{array}{l}\text { Increase ICS dose to } 800 \mathrm{mcg} \\
\text { together with chosen effective } \\
\text { regime from Step 3, and refer } \\
\text { to paediatrician }\end{array}$ \\
\hline & & $\begin{array}{l}\text { Refer all children for a } \\
\text { specialist Paediatric opinion }\end{array}$ \\
\hline $\begin{array}{l}\text { The lowest } p \\
\text { been achieve } \\
\text { therapies witl } \\
\text { Notes } \\
\text { 1. In smaller } \\
\text { when using s } \\
\text { prescribed do } \\
\text { 2. All childrer } \\
\text { advice as part } \\
\text { 3. Doubling t } \\
\text { 4. Theophyllir } \\
\text { through a pa } \\
\text { 5. All doses g }\end{array}$ & $\begin{array}{l}\text { wn } \\
\text { ssible dose of ICS should be used to } \\
\text { the ICS dose should be stepped do } \\
\text { drawn. Patients should then be revie } \\
\text { hildren, drug delivery is often a prob } \\
\text { acers. Care and time should be take } \\
\text { es match. } \\
\text { receiving }>400 \mathrm{mcg} \text { BDP or equivale } \\
\text { of a written plan. } \\
\text { e ICS dose during an exacerbation } \\
\text { e and nedocromil therapy should be } \\
\text { iway involving ICS, LABA and LTRA. } \\
\text { ven are total daily dose. }\end{array}$ & $\begin{array}{l}\text { achieve control. When control has } \\
\text { own where possible, or add on } \\
\text { ewed at an appropriate interval. } \\
\text { elem, with drug being wasted even } \\
\text { en to ensure that the delivered and } \\
\text { is should have steroid impact } \\
\text { considered only after working }\end{array}$ \\
\hline
\end{tabular}

should be part of a written action plan

- A Specialist Paediatrician should be involved in care and review

- Those with symptoms of shock and decreased consciousness should receive parenteral hydrocortisone and should be admitted to hospital for monitoring and treatment

Concomitant use of other steroid preparations such as creams and intra-nasal steroids must be taken into account when calculating risk/benefit.

Long-acting $\beta 2$-agonists (LABA)

When added to ICS therapy, LABAs are a safe treatment, improving lung function and symptoms, and reducing exacerbations. As with adults, ${ }^{35-37}$ they should always be an add-on treatment to ICS therapy, and should never be used as single agents in asthma. 
Leukotreine receptor antagonists (LTRAs)

LTRAs may improve lung function, reduce exacerbations and produce symptomatic improvements. In older children, they should normally be considered as add-on therapy, following on from ICS and LABA therapy. Nevertheless, in smaller children they may be used at an earlier stage should ICS therapy prove unsuitable. ${ }^{1,13}$ LTRAs are generally well tolerated and are available in different formulations for children of different ages.

Referral to a specialist respiratory paediatrician

Specialist options include;

- Review of the diagnosis

- Treatment with regular systemic steroids

- Monoclonal antibody therapy in children and adolescents 12 years and older

- Immunotherapy (children aged $>5$ years)

- Multi-disciplinary team management

\section{Loss of asthma control Asthma action plans and self management} Linda Pearce

Most asthma exacerbations develop slowly over a period of more than six hours. There should therefore be enough time to initiate appropriate action. Written personalised asthma action plans (PAAPs) can be introduced as part of a structured educational discussion with a trained asthma healthcare professional. ${ }^{43}$ Key components of an asthma educational programme ${ }^{44}$ are shown in Box 5, and the components of a written PAAP ${ }^{45}$ are shown in Box 6 .

The benefits of written PAAPs as part of self management education have been found to provide improved health outcomes. ${ }^{43,46}$ The benefits are most noticeable for those in secondary care with moderate to severe asthma. ${ }^{47}$ Therefore prior to discharge all patients should receive a written-PAAP.An acute consultation for deteriorating asthma in any health care setting provides an opportunity to reinforce the self management strategy.

\section{Difficult asthma, asthma exacerbations, and acute asthma}

Linda Pearce

Difficult asthma

The term 'difficult asthma' refers to patients with diagnosed asthma whose asthma-like symptoms and exacerbations persist, despite maximal treatment at step 4 or 5 of the guidelines. ${ }^{48,49}$ The factors contributing to difficult asthma and management recommendations are shown in Table 7.

Specific patient groups

There should be an awareness of the needs of certain groups of the population. People from certain ethnic subgroups have higher levels of hospital admissions and exacerbations. ${ }^{51}$ Socially disadvantaged groups, adolescents and young adults are less likely to attend for structured clinical review and are more likely to use emergency asthma healthcare services and also to have a higher reliance on bronchodilators. ${ }^{1}$ The communication difficulties with these groups should be considered when structuring educational

\section{Box 5. Key components of an asthma educational} programme. ${ }^{1}$

- $\quad$ Structured education, which may include

Nature of the disease

Nature of the treatment

How to use treatment, including inhaler technique and concordance Identification of the areas where the patient most wants treatment to have effect

Development of self monitoring/self assessment skills

Negotiation of the personalised action plan in the light of identified patient goals

Recognition and management of acute exacerbations

Appropriate allergen or trigger avoidance

- Reinforcement of structured education with written personal action plan, such as the Asthma UK action plan (www.asthma.org.uk/control)

- The education programme may be supported with resources available from Asthma UK through their website or their Advice line (08457 010203), which includes an interpreting service.

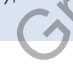

Box 6: Components of a written personalised asthma action $p$ ant.

\section{8}

- Specific advice about recognising loss of asthma control either through PEF measurements (after treatment has been optimised), symptoms, or both (PEF should be based on personal best in the last two years for adults, and should be updated more frequently in children).

Individualised actions if asthma deteriorates, including: When and how to increase medication When to commence a reserve emergency course of oral steroids, i.e. when symptoms continue or deteriorate and/or if PEF falls to $\leq 60 \%$ of their best

If ICS treatment has been reduced or stopped the patient should be reminded to increase the dose or to restart ICS

- Those on low doses (e.g. $200 \mathrm{mcg}$ total daily dose) may be advised to increase the dose to $1,200 \mathrm{mcg}$ daily at the onset of deterioration. Increasing ICS dose is ineffective if already taking $>400 \mathrm{mcg}$ total daily dose.

When and how to seek emergency help.

- There should be a maximum of 2-3 PEF action points. Usual points are PEF $\leq 80 \%$ best: - increase inhaled steroids if applicable PEF $\leq 60 \%$ best: - commence oral steroids

$\mathrm{PEF} \leq 40 \%$ best: - seek urgent medical advice

and self management programmes.

\section{Asthma deaths}

Confidential enquires into asthma deaths in the UK have demonstrated that the majority of people who die of asthma have severe disease and have behavioural and adverse psychosocial factors contributing to their death. Only a minority of asthma deaths are in patients considered to have mild or moderately severe disease, though sudden fatal attacks can still occur possibly triggered by aero-allergens. ${ }^{52.53}$ Inadequate treatment, inadequate objective monitoring of asthma and follow-up review, widespread underuse of written management plans, a heavy 
ML Levy et al.

Table 7. Factors contributing to difficult asthma. ${ }^{1}$

\begin{tabular}{|c|c|c|}
\hline Factors & Identification & Recommendation/Management \\
\hline Poor adherence & $\begin{array}{l}\text { Monitor repeat prescribing patterns } \\
\text { Ask open-ended questions about medication usage }\end{array}$ & $\begin{array}{l}\text { Negotiate treatment plans } \\
\text { Consider reminder strategies } \\
\text { Provide simple verbal and written instructions and } \\
\text { information on drug treatment }\end{array}$ \\
\hline $\begin{array}{l}\text { Psychosocial factors - } \\
\text { risk of developing fatal } \\
\text { and near-fatal asthma } \\
\text { (NFA) }\end{array}$ & $\begin{array}{l}\text { Severe asthma recognised by one or more of: } \\
\text { - } \text { previous NFA, eg previous ventilation or respiratory acidosis } \\
\text { - } \quad \text { previous admission for asthma especially if in the last year } \\
\text { - } \text { requiring three or more classes of asthma medication } \\
\text { - } \text { reaveated attendances at A+E for asthma care especially if in the last year } \\
\text { - "brittle" asthma } \\
\text { And } \\
\text { Adverse behavioural or psychosocial factors recognised by one or more of: } \\
\text { - non-compliance with treatment or monitoring } \\
\text { - } \text { failure to attend appointments } \\
\text { - } \text { self discharge from hospital } \\
\text { - } \text { psychosis, depression, other psychiatric illness or deliberate self harm } \\
\text { - } \text { current or recent major tranquilliser use } \\
\text { - } \text { denial } \\
\text { - alcohol or drug abuse } \\
\text { - obesity } \\
\text { - learning difficulties } \\
\text { - childhood abuse } \\
\text { - income problems } \\
\text { - } \text { employment problems }\end{array}$ & $\begin{array}{l}\text { Confirm diagnosis } \\
\text { Assess adherence to medication } \\
\text { Should be under specialist supervision indefinitely }\end{array}$ \\
\hline Dysfunctional breathing & $\begin{array}{l}\text { May be alternative or concomitant diagnosis. Chronic hyperventilation is not } \\
\text { clinically apparent and so diagnosis may be difficult. Patients may hyperventilate } \\
\text { more obviously when stressed and readilfy produce symptoms. PEFs may be normal. } \\
\text { May be persistently low arterial } \mathrm{pCO}_{2} \text { With high renal excretion of bicarbonate so } \\
\text { that pH is normal. } \\
\text { Occasional deep, sighing breaths may benoted. These keep the } \mathrm{pCO}_{2} \text { depressed. }\end{array}$ & $\begin{array}{l}\text { Consider principles of yoga and Buteyko breathing } \\
\text { technique to control hyperventilation }\end{array}$ \\
\hline Allergy & Frequent episodes of acute asthma & $\begin{array}{l}\text { Allergen testing for indoor allergens especially for } \\
\text { mould sensitivity. } \\
\text { No published evidence for any intervention }\end{array}$ \\
\hline
\end{tabular}

reliance on SABA therapy, and inappropriate prescriptions of betablocker therapy or heavy sedation, are all recognised contributory factors. ${ }^{54-57}$ Enquires have also identified a peak of asthma deaths in young people occurring in July and August, and in older people during December and January. Most deaths occur before admission to hospital. ${ }^{54-57}$

\section{At-risk registers}

It has been recommended that a register of patients 'at risk' should be established in general practices to identify people more likely to die from asthma. ${ }^{1,57}$ How ever, further research is needed. Asthma exacerbations and acute asthma

All reception staff and out-of-hours call takers should be aware that a person with asthma complaining of respiratory symptoms needs immediate access to a doctor or trained respiratory nurse. It is important to treat each acute asthma consultation in the same way as one would for acute severe asthma until reassured otherwise. A structured clinical assessment and a standardised recording system are associated with favourable outcomes in acute exacerbations. ${ }^{58}$

Assessment of acute asthma in adults

The factors used to assess asthma severity in adults are as follows;

- Clinical features: severe breathlessness (including being too breathless to complete sentences in one breath), tachypnoea, tachycardia, silent chest, cyanosis or collapse. None of these singly or together is specific and their absence does not exclude a severe attack.

- PEF or FEV $\mathrm{F}_{1}$ : both are useful and valid measures of airway calibre. PEF is more convenient and is cheaper. PEF expressed as a percentage of the patient's previous best value is most useful clinically, but expressed as \% predicted gives a rough guide in the absence of a known previous best value.

- Pulse oximetry: Measure oxygen saturation $\left(\mathrm{SpO}_{2}\right)$ with a pulse oximeter to determine the adequacy of oxygen therapy. The aim is to maintain $\mathrm{SpO}_{2}>92 \%$. 


\section{Table 8. Levels of severity of acute asthma exacerbations in adults [reproduced with permission].}

\begin{tabular}{|c|c|}
\hline $\begin{array}{l}\text { Life-threatening } \\
\text { asthma }\end{array}$ & 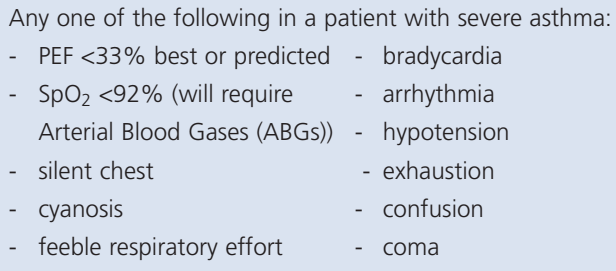 \\
\hline $\begin{array}{l}\text { Acute severe } \\
\text { asthma }\end{array}$ & $\begin{array}{l}\text { Any one of: } \\
\text { - } \text { PEF } 33-50 \% \text { best or predicted } \\
\text { - } \text { respiratory rate } \geq 25 / \mathrm{min} \\
\text { - } \text { heart rate } \geq 110 / \mathrm{min} \\
\text { - } \text { inability to complete sentences in one breath }\end{array}$ \\
\hline $\begin{array}{l}\text { Moderate asthma } \\
\text { exacerbation }\end{array}$ & $\begin{array}{l}\text { - Increasing symptoms } \\
\text { - PEF }>50-75 \% \text { best or predicted } \\
\text { - } \text { no features of acute severe asthma }\end{array}$ \\
\hline Brittle asthma & $\begin{array}{l}\text { - Type 1: wide PEF variability ( }>40 \% \text { diurnal variation } \\
\text { for }>50 \% \text { of the time over a period }>150 \text { days) } \\
\text { despite intense therapy } \\
\text { - Type } 2 \text { : sudden severe attacks on a background of } \\
\text { apparently well controlled asthma }\end{array}$ \\
\hline
\end{tabular}

The levels of severity of asthma exacerbations are shown in Table 8.

The treatment pathway and the criteria for admission for adults are shown in Figure 4.

Assessment of acute asthma in children aged $\geqslant 2$ years The clinical features for assessment of severity are shown in Table-9.

In addition, the following clinical signs should be accurately recorded:

- Pulse rate: increasing tachycardia generally denotes worsening asthma; a fall in heart rate in life threatening asthma is a preterminal event

- Respiratory rate and degree of breathlessness: i.e. is the child too breathless to complete sentences in one breath or to feed

- Use of accessory muscles of respiration: best noted by observation or by palpation of neck muscles

- Amount of wheezing: which might become biphasic or less apparent with increasing airways obstruction. N.B. intensity of wheezing is not a marker of severity

- Degree of agitation and conscious level: always give calm reassurance

Clinical signs often correlate poorly with severity of obstruction..$^{59.60}$ Therefore, objective measurement of PEF - if the child is over the age of 5 years - and $\mathrm{SpO}_{2}$ is essential.

The treatment pathway and criteria for admission for children are shown in Figure 5.

Assessment of acute asthma in children aged $<2$ years The assessment of acute asthma in early childhood is difficult. Most infants are audibly wheezy with intercostal recession but are not distressed. If an infant has signs and symptoms suggesting
Figure 4. Management of acute severe asthma in adults in general practice [reproduced with permission].

\begin{tabular}{|c|c|c|c|}
\hline \multicolumn{2}{|c|}{$\begin{array}{l}\text { Many deaths from asthma are preventable. Delay } \\
\text { can be fatal. Factors leading to poor outcome } \\
\text { include: } \\
\text { - Clinical staff. Failing to assess severity by objective } \\
\text { measurement } \\
\text { Patients or relatives failing to appreciate severity } \\
\text { Regarder-use of ocorticosteroids } \\
\text { acute severe asthency asthma consultation as for } \\
\text { Reghil shown otherwise. }\end{array}$} & \multicolumn{2}{|c|}{$\begin{array}{l}\text { Assess and record: } \\
\text { Peak expiratory flow (PEF) } \\
\text { Symptoms and response to self treatment } \\
\text { Heart and respiratory rates } \\
\text { Oxygen saturation (by pulse oximetry, if available) } \\
\text { Caution: Patients with severe or life threatening attacks } \\
\text { may not be distressed and may not have all the } \\
\text { abnormalities listed below. The presence of any should } \\
\text { alert the doctor. }\end{array}$} \\
\hline Moderate asthma & \multicolumn{2}{|c|}{ Acute severe asthma } & Life threatening asthma \\
\hline \multicolumn{4}{|c|}{ INITIAL ASSESSMENT } \\
\hline PEF $>50 \%$ best $\mathrm{O}$ & \multicolumn{2}{|c|}{ 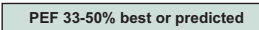 } & PEF $<33 \%$ best or predicted \\
\hline \multicolumn{4}{|c|}{ FURTHER ASSESSMENT } \\
\hline $\begin{array}{l}\text { - Speech normal } \\
\text { - Respiration < } 25 \text { breaths } / \text { min } \\
\text { - Pulse }<110 \text { beats/min }\end{array}$ & \multicolumn{2}{|c|}{$\begin{array}{l}\text { - Can't complete sentences } \\
\text { - Respiration } \geq 25 \text { breaths/min } \\
\text { Pulse } \geq 110 \text { beats } / \mathrm{min}\end{array}$} & $\begin{array}{l}\text { - } \mathrm{SpO}_{2}<92 \% \\
\text { - Silent chest, cyanosis or feeble } \\
\text { respiratory effort } \\
\text { - Bradycardia, dysrhythmia or } \\
\text { hypotension } \\
\text { - Exhaustion, confusion or coma }\end{array}$ \\
\hline \multicolumn{4}{|c|}{ MANAGEMENT } \\
\hline \multicolumn{3}{|l|}{$\begin{array}{l}\text { Treat at home or in surgery and } \\
\text { ASSESS RESPONSE TO } \\
\text { TREATMENT } \\
\end{array}$} & Arrange immediate ADMISSION \\
\hline \multicolumn{4}{|c|}{ TREATMENT } \\
\hline 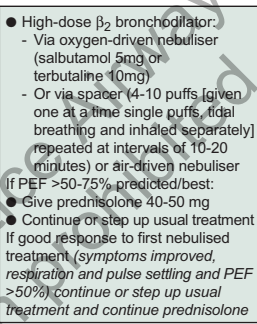 & \multicolumn{2}{|c|}{\begin{tabular}{|l} 
- Oxygen $40-60 \%$ if available \\
- High-dose $\beta_{2}$ bronchodilator: \\
- Via oxygen-driven nebuliser \\
(salbutamol $5 \mathrm{mg}$ or \\
terbutaline $10 \mathrm{mg}$ ) \\
- Or via spacer (4-10 puffs [given \\
one at a time single puffs, tidal \\
breathing and inhaled \\
separately] repeated at intervals \\
of $10-20$ minutes) \\
- Prednisolone $40-50 \mathrm{mg}$ or IV \\
hydrocortisone $100 \mathrm{mg}$ \\
- If no resonse in acute severe \\
asthma: ADMIT
\end{tabular}} & $\begin{array}{l}\text { Oxygen } 40-60 \% \\
\text { Prednisolone } 40-50 \mathrm{mg} \text { or IV } \\
\text { hydrocortisone } 100 \mathrm{mg} \\
\text { immediately } \\
\text { - High-dose } \beta_{2} \text { bronchodilator and } \\
\text { ipratropium: } \\
\text { - Via oxygen-driven nebuliser } \\
\text { (salbutamol } 5 \mathrm{mg} \text { or } \\
\text { terbutaline } 10 \mathrm{mg} \text { ) and } \\
\text { ipratropium } 0.5 \mathrm{mg} \text { ) } \\
\text { - Or via spacer }(4-10 \text { puffs [given } \\
\text { one at a time single puffs, tidal } \\
\text { breathing and inhaled } \\
\text { separately] repeated at intervals } \\
\text { of } 10-20 \text { minutes }\end{array}$ \\
\hline$>$ & \multicolumn{2}{|c|}{$\gamma$} & $>$ \\
\hline $\begin{array}{l}\text { Admit to hospital if any : } \\
\text { - life threatening features } \\
\text { - features of acute severe asthma } \\
\text { present after initial treatment } \\
\text { - previous near-fatal asthma } \\
\text { Lower threshold for admission if } \\
\text { afternoon or evening attack, recent } \\
\text { nocturnal symptoms or hospital } \\
\text { admission, previous severe attacks, } \\
\text { patient unable to assess own } \\
\text { condition, or concern over social } \\
\text { circumstances }\end{array}$ & \multicolumn{2}{|c|}{$\begin{array}{l}\text { If admitting the patient to hospital: } \\
\text { - Stay with patient until ambulance } \\
\text { arrives } \\
\text { - Send written assessment and } \\
\text { referral details to hospital } \\
\text { G Give high-dose } \beta_{2} \\
\text { bronchodilator via oxygen-driven } \\
\text { nebuliser in ambulance }\end{array}$} & $\begin{array}{l}\text { Follow up after treatment or } \\
\text { discharge from hospital: } \\
\text { - GP review within } 48 \text { hours } \\
\text { - Monitor symmptoms and PEF } \\
\text { - Check inhaler technique } \\
\text { - Written asthma action plan } \\
\text { - Modify treatment according to } \\
\text { guidelines for chronic persistent } \\
\text { asthma } \\
\text { - Address potentially preventable } \\
\text { contributors to admission }\end{array}$ \\
\hline
\end{tabular}

Table 9. Clinical features used to assess asthma severity in children aged over two years [reproduced with permission].

\begin{tabular}{|c|c|c|}
\hline \multicolumn{2}{|c|}{ Acute severe } & Life-threatening \\
\hline \multirow{2}{*}{\multicolumn{2}{|c|}{$\begin{array}{l}\text { Can't complete sentences in one breath or too } \\
\text { breathless to talk or feed }\end{array}$}} & Silent chest \\
\hline & & Cyanosis \\
\hline \multirow[t]{2}{*}{ Pulse } & $>120$ in children aged $>5$ years & Poor respiratory effort \\
\hline & $>130$ in children aged $2-5$ years & Hypotension \\
\hline \multirow[t]{3}{*}{ Respiration } & $>30$ breaths $/$ min aged $>5$ years & Exhaustion \\
\hline & $>50$ breaths/min aged $2-5$ years & Confusion \\
\hline & & Coma \\
\hline
\end{tabular}

differing severities, always treat according to the most severe features and consider admission to hospital. See Table 10.

Treatment of acute asthma

For all ages, once the level of severity has been established, treatment should commence immediately and be continued whilst 
ML Levy et al.

Figure 5. Management of acute asthma in children in general practice [reproduced with permission].

\begin{tabular}{|c|c|c|c|c|c|c|c|}
\hline \multicolumn{4}{|c|}{ Age 2-5 years } & \multicolumn{4}{|c|}{ Age $>5$ years } \\
\hline \multicolumn{4}{|c|}{ ASSESS ASTHMA SEVERITY } & \multicolumn{4}{|c|}{ ASSESS ASTHMA SEVERITY } \\
\hline \begin{tabular}{|l|} 
Moderate exacerbation \\
- $\mathrm{SpO}_{2} \geq 92 \%$ \\
Able to talk \\
- Heart rate $\leq 130 / \mathrm{min}$ \\
- Respiratory rate $\leq 50 / \mathrm{min}$
\end{tabular} & \multicolumn{2}{|c|}{$\begin{array}{l}\text { Severe exacerbation } \\
\text { : } \mathrm{SpO}_{2}<92 \% \\
\text { Too breathless to talk } \\
\text { - Heart rate }>130 / \mathrm{min} \\
\text { - Respiratory rate }>50 / \mathrm{min} \\
\text { - Use of accessory neck } \\
\text { muscles }\end{array}$} & $\begin{array}{l}\text { Life threatening asthma } \\
\mathrm{SpO}_{2}<92 \% \text { plus any of: } \\
\text { Silent chest } \\
\text { Poor respiratory effort } \\
\text { - Agitation } \\
\text { - Altered consciousness } \\
\text { - Cyanosis }\end{array}$ & \begin{tabular}{|l} 
Moderate exacerbation \\
- $\mathrm{SpO}_{2} \geq 92 \%$ \\
PEF $\geq 50 \%$ best or \\
predicted \\
- Able to talk \\
- Heart rate $\leq 120 / \mathrm{min}$ \\
- Respiratory rate $\leq 30 / \mathrm{min}$
\end{tabular} & \multicolumn{2}{|c|}{$\begin{array}{l}\text { Severe exacerbation } \\
\text { - } \mathrm{SpO}_{2}<92 \% \\
\text { - } \mathrm{PEF} \geq 50 \% \text { best or } \\
\text { predicted } \\
\text { - Too breathless to talk } \\
\text { - Heart rate }>120 / \mathrm{min} \\
\text { - Respiratory rate }>30 / \mathrm{min} \\
\text { - Use of accessory neck } \\
\text { muscles }\end{array}$} & $\begin{array}{l}\text { Life threatening asthma } \\
\mathrm{SpO}_{2}<92 \% \text { plus any of: } \\
\text { - PEF }<33 \% \text { best or } \\
\text { predicted } \\
\text { - Silent chest } \\
\text { - Poor respiratory effort } \\
\text { - Agitation } \\
\text { - Altered consciousness } \\
\text { - Cyanosis }\end{array}$ \\
\hline $\begin{array}{l}\text { - } \beta_{2} \text {-agonist } 4-6 \text { puffs via } \\
\text { spacer } \pm \text { facemask } \\
\text { - Consider soluble } \\
\text { prednisolone } 20 \mathrm{mg}\end{array}$ & \multirow{2}{*}{\multicolumn{2}{|c|}{\begin{tabular}{|l|} 
Oxygen via facemask \\
- -6 puffs of $\beta_{2}$-agonist \\
[given one at a time single \\
puffs,tidal breathing and \\
inhaled separately] at \\
intervals of $10-20$ minutes \\
or nebulised salbutamol \\
$2.5 \mathrm{mg}$ or terbutaline $5 \mathrm{mg}$ \\
- Soluble prednisolone $20 \mathrm{mg}$
\end{tabular}}} & \multirow{2}{*}{$\begin{array}{l}\text { - Oxygen via facemask } \\
\text { - Nebulise: } \\
\text { - salbutamol } 2.5 \mathrm{mg} \\
\text { or terbutaline } 5 \mathrm{mg} \\
+ \\
\text { - ipratropium } 0.25 \mathrm{mg} \\
\text { - Soluble prednisolone } \\
20 \mathrm{mg} \\
\text { or } \\
\text { IV hydrocortisone } \\
50 \mathrm{mg}\end{array}$} & $\begin{array}{l}\text { - } \beta_{2} \text {-agonist 4-6 puffs via } \\
\text { spacer } \\
\text { - Consider soluble } \\
\text { prednisolone } 30-40 \mathrm{mg}\end{array}$ & \multirow{2}{*}{\multicolumn{2}{|c|}{$\begin{array}{l}\text { Oxygen via facemask } \\
\text {-6-6 puffs of } \beta_{2} \text {-agonist } \\
\text { [given one at a time single } \\
\text { puffs,tidal breathing and } \\
\text { inhaled separately] at } \\
\text { intervals of } 10-20 \text { minutes } \\
\text { or nebulised salbutamol } \\
2.5-5 \mathrm{mg} \text { or terbutaline } \\
5-10 \mathrm{mg} \\
\text { - Soluble prednisolone } \\
30-40 \mathrm{mg} \text {. } \\
\end{array}$}} & $\begin{array}{l}\text { Oxygen via facemask } \\
\text { - Nebulise: } \\
\text { - salbutamol } 5 \mathrm{mg} \\
\quad \text { or terbutaline } 10 \mathrm{mg} \\
\quad+ \\
\text {-ipratropium } 0.25 \mathrm{mg}\end{array}$ \\
\hline $\begin{array}{c}\text { Increase } \beta_{2} \text {-agonist dose } \\
\text { by } 2 \text { puffs every } 2 \text { minutes } \\
\text { up to } 10 \text { pufff according } \\
\text { to response }\end{array}$ & & & & $\begin{array}{l}\text { Increase } \beta_{2} \text {-agonist dose } \\
\text { by } 2 \text { puffs every } 2 \text { minutes }\end{array}$ & & & $\begin{array}{l}\text { - Soluble prednisolone } \\
30-40 \mathrm{mg} \\
\text { or } \\
\text { IV hydrocortisone }\end{array}$ \\
\hline$>$ & \multicolumn{2}{|c|}{$\gamma$} & $>$ & $\gamma$ & \multirow{2}{*}{\multicolumn{2}{|c|}{$\begin{array}{l}\text { IF POOR RESPONSE } \\
\text { REPEAT } \beta_{2} \text {-AGONIST } \\
\text { AND ARRANGE } \\
\text { ADMISSION } \\
\end{array}$}} & $>$ \\
\hline $\begin{array}{l}\text { IF POOR RESPONSE } \\
\text { ARRANGE ADMISSION }\end{array}$ & $\begin{array}{l}\text { IF POOF } \\
\text { REPEAT } \\
\text { AND } \\
\text { ADI }\end{array}$ & $\begin{array}{l}\text { RESPONSE } \\
\text { 2-AGONIST } \\
\text { SSIONE } \\
\end{array}$ & $\begin{array}{l}\text { REPEAT } \beta_{2} \text {-AGONIST VIA } \\
\text { OXYGEN-DRIVEN } \\
\text { NEBULISER WHILST } \\
\text { ARRANGING IMMEDIATE } \\
\text { HOSPITAL ADMISSION } \\
\end{array}$ & $\begin{array}{l}\text { IF POOR RESPONSE } \\
\text { ARRANGE ADMISSION }\end{array}$ & & & $\begin{array}{l}\text { REPEAT } \beta_{2} \text {-AGONIST VIA } \\
\text { OXYGEN-DRIVEN } \\
\text { NEBULISER WHILST } \\
\text { ARRANGING IMMEDIATE } \\
\text { HOSPITAL ADMISSION } \\
\end{array}$ \\
\hline \multicolumn{2}{|c|}{$\begin{array}{l}\text { GOOD RESPONSE } \\
\text { - Continue } \beta_{2} \text {-agonist via spacer or nebuliser, } \\
\text { as needed but not exceeding 4-hourly } \\
\text { - If symptoms are not controlled repeat } \\
\beta_{2} \text {-agonist and refer to hospital } \\
\text { - Continue prednisolone for up to } 3 \text { days } \\
\text { - Arrange follow-up clinic visit } \\
\end{array}$} & \multicolumn{2}{|c|}{\begin{tabular}{|l|} 
POOR RESPONSE \\
- Stay with patient until ambulance arrives \\
- Send written assessment and referral details \\
- Repeat $\beta_{2}$-agonist via oxygen-driven \\
nebuliser in ambulance
\end{tabular}} & \multicolumn{2}{|c|}{$\begin{array}{l}\text { GOOD RESPONSE } \\
\text { - Continue } \beta_{2} \text {-agonist via spacer or nebuliser, } \\
\text { as needed but not exceeding 4-hourly } \\
\text { - If symptoms are not controlled repeat } \\
\beta_{2} \text {-agonist and refer to hospital } \\
\text { Continue prednisolone for up to } 3 \text { days } \\
\text { Arrange follow-up clinic visit }\end{array}$} & \multicolumn{2}{|c|}{$\begin{array}{l}\text { POOR RESPONSE } \\
\text { : Stay with patient until ambulance arrives } \\
\text { - Send written assessment and referral details } \\
\text { - Repeat } \beta_{2} \text {-agonist via oxygen-driven } \\
\text { nebuliser in ambulance }\end{array}$} \\
\hline \multicolumn{4}{|c|}{\begin{tabular}{|l|} 
LOWER THRESHOLD FOR ADMISSION IF: \\
- Attack in late afternoon or at night \\
- Recent hospital admission or previous severe attack \\
- Concern over social circumstances or ability to cope at home \\
\end{tabular}} & \multicolumn{3}{|c|}{$\begin{array}{l}\text { LOWER THRESHOLD FOR ADMISSION IF: } \\
\text { - Attack in late afternoon or at night } \\
\text { Recent hospital admission or previous severe attack } \\
\text { - Concern over social circumstances or ability to cope at home }\end{array}$} & $\begin{array}{l}\text { NB: If a patient has signs and } \\
\text { symptoms across categories, } \\
\text { always treat according to } \\
\text { their most severe features }\end{array}$ \\
\hline
\end{tabular}

Table 10. Clinical features used to assess asthma severity in children aged less than 2 years. ${ }^{1}$

\begin{tabular}{lll} 
Moderate & Severe & Life-threatening \\
\hline $\mathrm{SpO}_{2} \geq 92 \%$ & $\mathrm{SpO}_{2}<92 \%$ & Apnoea \\
Audible wheezing & Cyanosi5 & Bradycardia \\
Using accessory muscles & Marked respiratory & Poor respiratory effort \\
Still feeding & distress & \\
& Too breathless to feed &
\end{tabular}

waiting for the ambulance if hospitalisation is indicated. Management of acute asthma in pregnancy is the same as for a non-pregnant woman. ${ }^{1,61,62}$

Oxygen and $\beta 2$-agonist bronchodilators

Hypoxia is dangerous. If in doubt give oxygen and maintain oxygen saturations of at least $92 \%$. All adults with acute severe or life threatening asthma should urgently receive nebulised $\beta_{2}$ agonist bronchodilators with oxygen given at a flow rate of 6 litres/min (so the oxygen cylinders need a high flow regulator ${ }^{63}$ )

For children and infants, high flow oxygen should be administered via a tight-fitting oxygen mask or at a sufficiently high flow rate through nasal cannulae.
In adults and children with acute asthma without life threatening features, $\beta_{2}$-agonists can be administered by repeated activation of a $\mathrm{pMDI}$ via a large volume spacer, 4-10 puffs given one at a time in single puffs, inhaled via tidal breathing and repeated at intervals of 10-20 minutes. $^{64}$ For children and infants, a spacer with a face mask may be used. For all ages, oxygen, if available, should be administered between doses of $\beta_{2}$-agonists.

Children who do not improve after up to 10 puffs of $\beta_{2}$ agonist should be referred to hospital. ${ }^{65}$

If a spacer is not available, an air-driven nebuliser may also be used to administer either salbutamol $5 \mathrm{mgs}$ (2.5-5mg for infants and children) or terbutaline $10 \mathrm{mgs}$ (5-10mgs for infants and children). High doses of $\beta_{2}$-agonist bronchodilators may induce hypoxia due to ventilation/perfusion inadequacy. For acute severe or life-threatening asthma the addition of nebulised ipratropium bromide $0.5 \mathrm{mgs}(0.25 \mathrm{mgs}$ if $<2$ years old $)$ may be considered.

Steroid therapy

Steroid tablets are as effective as injected steroids, provided they can be swallowed and retained. The earlier they are given in the acute attack the better the outcome. ${ }^{66}$ An adequate dose for an adult is 40-50mgs daily for at least five days or until recovery. These may be given as $25 \mathrm{mg} \times 2$, or $5 \mathrm{mg} \times 8-10$, tablets. If 
Table 11. Practical advice on possible asthma audits.

\begin{tabular}{|c|c|c|}
\hline Audit criteria & Procedure & Action \\
\hline $\begin{array}{l}\text { 1. The percentage of children using } \\
>800 \mathrm{mcg} / \text { day of inhaled } \\
\text { beclametasone. Standard }<5 \% \text {, } 71 \\
\text { 2. The proportion of these who are } \\
\text { under the care of a specialist } \\
\text { respiratory paediatrician. } \\
\text { Standard } 100 \%\end{array}$ & $\begin{array}{l}\text { - Search for children (aged }<12 \text { years) using ICS } \\
\text { - Print out the year's prescriptions and calculate the mean daily dose. (Focusing } \\
\text { on children using higher dose inhalers will make this more manageable, } \\
\text { though may miss a few using multiple doses of a low dose inhaler). } \\
\text { 1. Calculate the percentage on high dose ICS as a proportion of all children } \\
\text { 2. Check the records of those on high dose ICS for evidence of a referral to a } \\
\text { paediatrician }\end{array}$ & $\begin{array}{l}\text { As a practice, review the evidence for } \\
\text { safe use of ICS in children and revise } \\
\text { (or devise) a practice policy }\end{array}$ \\
\hline
\end{tabular}

1. The percentage of patients in whom there is a record of a check of inhaler technique. Standard $>70 \%{ }^{73}$

2. The proportion with poor technique in whom (sustainable) action has been taken. Standard 100\% ${ }^{1}$

1. The percentage of patients with an acute asthma attack where objective evidence of severity has been clearly documented. Standard $\mathbf{1 0 0} \%$

1. The percentage of pregnant women with asthma who have a review of their asthma management. Standard $100 \%^{1}$ onset asthma for whom an occupational cause has been considered.

2. The proportion of those with possible occupational causes who have had serial PEFs recorded. Standard 100\%

3. The proportion of those with suspected occupational asthma referred to a chest physician. Standard $100 \%$
- Search for patients with the Read code 6637: Inhaler technique checked

- Identify patients noted to have 'poor' technique (say) 6-12 months ago (via computer if the assessment has been recorded)

1. Calculate the percentage with inhaler technique checked

2. Check to see what action was taken (e.g. change of device (Read code $671 \mathrm{M})$, spacer provided, technique taught) and whether this had been sustained (e.g. "still using the 'new' inhaler").
As a practice, decide who is responsible for checking inhaler technique and what actions they are able to take. E.g. decide who will change the repeat prescriptions so that the patient does not revert to an inhaler they cannot use.
- Search for patients with an acute exacerbation (e.g Read code H333) in the last year. (or consider searching for courses of prednisolone)

1. Check the clinical entry for a clinical observation such as (unable/able to speak in sentences, chest signs, a peak flow reading (Read code 3395), ideally compared to the patient's best PEF, respiratory rate, oxygen saturation.

2. Note whether you can decide on the severity of the attâck (see Tables 8-10). If it is not clear to you, then neither will it be clear to the coroner......

- Search for patients with a diagnosis of asthma(Read co

Search for patients with a diagnosis of asthma (Read code H33) who have had a confinement in (say) the last year.

1. Search for those who have had an asthma review (Read codes 66YJ, 66YK, 90JA) during the course of the pregnancy. Ideally this should be shortly after the confirmation of the pregnancy, and should include patients who are currently asymptomatic; the severity of asthma worsens in one-third of patients

$x$

- Search for adults (e.g. 25-60 yrs old) diagnosed with asthma in the last year (Read code H33)

1. Check the record for evidence that an occupational cause has been considered (e.g. the patient's job is noted, the answers to the screening questions are recorded)

2. In those in a high risk job, or where the answers to the screening questions raise the possibility of an occupational cause, check for evidence of PEF charting (Read code 663S)

3. If occupational asthma is suspected check for evidence of referral to a chest physician.
There is a medico-legal, as well as a clinical imperative to record the severity of an asthma attack. Ensure there are no practical barriers in your practice (e.g. no PEF meter, or no mouthpieces). Consider purchasing an oximeter.
Arrange a meeting to include the practice midwives and asthma nurses. Discuss the chapter on asthma in pregnancy and devise a protocol for ensuring that ladies are referred for an asthma review early in their pregnancy
The most likely outcome of this audit is that occupational causes are rarely considered. An in-house training on occupational asthma in order to raise awareness may be appropriate.
1. The percentage of patients who have had a discussion about selfmanagement in the last year. Standard $70 \%{ }^{73}$

2. The proportion with a written asthma action plan. Standard $>30 \%{ }^{12,76}$
1. Search for patients who have had a discussion about self-management in the last year. (Read code $663 \mathrm{U}$ or 6675). (The $70 \%$ standard reflects the poor attendance at asthma reviews).

2. Check the records for evidence that a written action plan has been given. If this is not routinely recorded, then a survey of patients is needed. About a third of people with asthma have written asthma action plans so a practical standard has been set at $30 \%$ - in reality it should be much higher!
Arrange to discuss the outcome with the team: implementing selfmanagement benefits from an organisational approach. ${ }^{76}$ Agree on the format(s) that plans will take, who will undertake the initial selfmanagement education and how other members of the team can reinforce advice. 
ML Levy et al.

injectable steroid is required IM or IV hydrocortisone $100 \mathrm{mg}$ should be administered.

Soluble prednisolone should be administered in a dose of 10 $\mathrm{mg}$ for infants, $20 \mathrm{mg}$ for children $2-5$ years and $30-40 \mathrm{mg}$ for older children. A course of up to three days is usually sufficient.

As part of the chronic asthma management plan, ICS should be continued or commenced as soon as possible whilst taking steroid tablets.

Following recovery, oral steroids can be stopped abruptly ${ }^{67}$ provided the patient is using ICS and is not taking maintenance oral systemic steroids. The rare exception is when oral steroid treatment is required for three or more weeks.

\section{Review}

Following an exacerbation of asthma, close follow-up is essential to ensure recovery, to elicit the reason for the exacerbation, and to explore the use of the PAAP.

For adults who have been admitted to hospital, follow-up should be arranged with the GP or asthma nurse within two working days following discharge from emergency department or hospital. A hospital specialist follow-up is often recommended about one month after admission.

For children, the recommendations are that the child should be followed-up by their GP within a week and should be seen in the paediatric asthma clinic within one to two months.

For both adults and children, follow-up timescales should be adapted for individual patients depending on clinical, psychosocial and behavioural factors.

\section{Asthma outcomes and audit in primary care}

Hilary Pinnock

A feature of the $2008 \mathrm{BTS} / \mathrm{SIGN}$ guideline is the inclusion of audit criteria explicitly linked to key recommendations. Audit and feedback is a recognised strategy for vimproving the quality of care, ${ }^{68}$ with standards increasingly being set and monitored within healthcare systems. ${ }^{69}$

\section{Pharmacological management}

The suggested audit criteria in the new guideline reflect concerns about the side effects of high dose ICS and the benefits of add-on therapy to improve control. ${ }^{1}$ A quarter of adults with asthma are being prescribed 'high-dose' ICS, a third with no concurrent prescription for add-on therapy, ${ }^{70}$ and $5 \%$ of children are being prescribed ICS at twice the recommended maximum dose. ${ }^{71}$ The risk of adrenal suppression from excessive doses of ICS means that such children should be under the care of a paediatrician. ${ }^{1}$

Auditing patient adherence with medication is complicated. Prescribed medication may not always be dispensed, so surrogate measures - such as calculating the average daily dose from the total number of inhalers prescribed - may be used. In addition, different inhaler devices not only contain different strengths of drug but also different numbers of doses.

Inhaler technique should be checked at every opportunity. The BTS/SIGN guideline recommends auditing the percentage of patients with satisfactory inhaler technique. ${ }^{1}$ However, it may be more useful to audit how often the initial prescribing of an inhaler is preceded by a check of technique so that the device chosen is suitable for the patient from the start.

\section{Acute asthma}

On behalf of the GPIAG, Neville et al undertook a national audit in 1991 which identified shortcomings in primary care management of acute asthma..$^{72} \mathrm{~A}$ key issue is the lack of objective assessment of severity, which not only compromises patient safety but also has important medico-legal implications. Subsequent GPIAG educational projects have focused on these issues, ${ }^{73,74}$ and the UNSAFE audit [available from www.guideline-audit.com] is an online resource for health professionals to evaluate their care of patients with uncontrolled asthma.

\section{Asthma in pregnancy}

Asthma treatment is safe in pregnancy and should be adjusted to maintain optimal control ${ }^{1} A$ simple audit in the author's practice highlighted that routine referral for an asthma review at the beginning of pregnancy was rare, in contrast to women with diabetes or heart disease; this resulted in a training programme for midwives and the establishment of a routine referral procedure. Asthma reviews and self-management education The UK Quality and Outcome Framework (QOF) ensures that practices audit the percentage of patients receiving asthma review $\mathrm{s}^{15}$ but the content of the review varies between practices. The 2008 guideline emphasises that a key component is the provision of a written PAAP. There is a Read code for self management education which could form the basis of an audit.

Table 11 gives examples of asthma audits which can be carried out in practice, together with advice on appropriate criteria and standards.

\section{Acknow ledgement}

We are grateful to the two referees for their constructive comments.

The authors and the editors gratefully acknowledge the support of the GPIAG, the PCRJ publisher Sherborne Gibbs Limited, and the BTS/SIGN Executive during the production of this supplement.

\section{Funding}

The production of this supplement was funded by Sherborne Gibbs Limited.

\section{Conflict of interest declaration}

Mark L Levy is Editor-in-Chief of the PCRJ. He has accepted sponsorship from GlaxoSmithKline (GSK), AstraZeneca (AZ), Trinity-Cheisi, Merck Sharp and Dohme (MSD), Merck, Altana Pharma, Novartis, Meda Pharmaceuticals, 3M Pharmaceuticals and Schering Plough for attending conferences. He has accepted lecture fees from Boehringer Ingelheim, GSK, AZ and Alk-Abello. He has been on advisory boards or provided consultancy for Schering Plough, MSD, Trinity-Cheisi, Altana Pharma, Ranbaxy, AZ, 3M Pharmaceuticals and Novartis. In addition, he has received research grants from GSK, Schering Plough, Boehringer Ingelheim, Pfizer, and $\mathrm{AZ}$. He is a member of ADMIT, (The Aerosol Drug Management Improvement Team) which is funded by an educational grant from M EDA Pharmaceuticals

Mike Thomas has, in the last three years, received fees for acting as a consultant from MSD, Schering and GSK. He has received honoraria for speaking at sponsored meetings from the following companies marketing respiratory and allergy products: AZ, Boehringer Ingelheim, GSK, MSD, Schering-Plough, Teva. He has received honoraria for attending advisory panels from Altana, AZ, BI, GSK, MSD, Merck Respiratory, Schering-Plough and Teva. He has received sponsorship to attend 
international scientific meetings from GSK, MSD and AZ, and has received funding for research projects from GSK, MSD and AZ. He holds a research fellowship from Asthma UK. Neither he nor any member of his close family has any shares in pharmaceutical companies.

lain R Small has recieved honoraria for giving lectures, and travel support to attend international conferences, from; GSK, AZ, Trinity-Chiesi, BoehringerIngelheim, Nycomed and MSD. Neither he nor his family own any shares in pharmaceutical companies

Linda Pearce has received speaker fees, and/or remuneration for attending advisory board meetings, and/or sponsorship to attend meetings, from the following pharmaceutical companies: Boehringer Ingelheim, Pfizer, Trinity Chiesi, GSK, Altana Pharma, MSD, AZ. Neither she nor her family own any shares in pharmaceutical companies.

Hilary Pinnock has, within the last year, spoken at, or chaired, education meetings sponsored by GSK, Schering Plough, Boehringer-Ingelheim, AZ, and has edited a web-publication sponsored by an educational grant from Pfizer. She has been sponsored to attend international conferences by GSK and AZ.

Paul Stephenson is the Deputy Editor and Supplements Editor of the PCRJ. He has received speaker fees, and/or remuneration for attending advisory board meetings, and/or sponsorship to attend international meetings, from the following pharmaceutical companies: AZ, GSK, Altana Pharma, MSD, 3M and Yamanouchi. Neither he nor his family own any shares in pharmaceutical companies.

\section{References}

1. British Thoracic Society, Scottish Intercollegiate Guidelines Network. British Guideline on the Management of Asthma. Thorax 2008;63(Suppl 4):iv1-iv121.

2. GINA. The Global Strategy for Asthma Management and Prevention, Global Initiative for Asthma (GINA) Updated 2007. Available from: http://www.ginasthma.org.

3. van der Molen T, Ostrem A, Stallberg B, Ostergaard MS, Singh RB. International Primary Care Respiratory Group (IPCRG) Guidelines: Management of asthma. Prim Care Resp J 2006;15(1):35-47. doi:10.1016/j.pcrj.2005.11.001

4. van Schayck CPO, Levy ML, Stephenson P, Sheikh A. The IPCRG Guidelines: Developing guidelines for managing chronic respiratory diseases in primary care. Prim Care Resp J 2006;15(1):1-4. doi:10.1016/j.pcrj.2005.12.003

5. Levy ML, Fletcher M, Price DB, Hausen T, Halbert RJ, Yawn BP. International Primary Care Respiratory Group (IPCRG) Guidelines: Diagnosis of respiratory diseases in primary care. Prim Care Resp J 2006;15(1):20-34. doi:10.1016/j.perj.2005.10,004

6. English RG, Bateman ED, Zwarenstein MF. Development of a South African integrated syndromic respiratory disease guideline forprimary care.Prim Care Resp J 2008;17(3):156-63. doi:10.3132/pcrj.2008.00044

7. O'Byrne PM. Asthma Management Guidelines: The issue of implementation. Prim Care Resp J 2006;15(1):5-6. doi:10.1016/j.pcrj.2005.11.005

8. Tomlins R. International Primary Care Respiratory Group (IPCRG) Guidelines: Dissemination and Implementation - a proposed course of action. Prim Care Resp J 2006;15(1):71-4. doi:10.1016/j.pcrj.2005.11.004

9. Royal College of Family Physicians, Office of Population Censuses and Surveys, Department of Health and Social Security. Morbidity statistics from general practice 1981-1982. Third National Study. Series M B5 No. 1. London. Her Majesty's Stationery Office, 1982

10. Tirimanna PRS, van Schayck CP, den Otter JJ et al. Prevalence of asthma and COPD in general practice in 1992: has it changed since 1977? Br J Gen Pract 1996;46:27781.

11. Taylor DR, Bateman ED, Boulet L-P, et al. A new perspective on concepts of asthma severity and control. Eur Respir J 2008;32:545-54.

12. Haughney J, Barnes G, Partridge M, Cleland J. The Living \& Breathing Study: A study of patients' views of asthma and its treatment. Prim Care Resp J 2004;13(1):28-35. doi:10.1016/j.pcrj.2003.11.007

13. Bush A. Diagnosis of asthma in children under five. Prim Care Resp J 2007;16(1):715. doi:10.3132/pcrj.2007.00001

14. Blanc PD, Israel L, Yelin EH, Eisner MD, Blanc PD. The association between occupation and asthma in general medical practice. Chest 1999;115(5):1259-64.

15. Burge PS. New guidelines for the management of occupational asthma in primary care and occupational health. Prim Care Resp J 2004;13(3):131-2. doi:10.1016/ j.pcrj.2004.06.001

16. Douglas JDM. If you want to cure their asthma, ask about their job. Prim Care Resp J 2005;14(2):65-71. doi:10.1016/j.pcrj.2004.12.002

17. Newman Taylor AJ, Nicholson PJ. Guidelines for the prevention, identification and management of occupational asthma: Evidence review and recommendations. London: British Occupational Health Research Foundation. 2004 [cited 2004 Dec 12];Available from: URL: http://www.bohrf.org.uk/content/asthma.htm

18. Levy ML, Nicholson PJ. Occupational asthma case finding: A role for primary care. $\mathrm{Br}$ J Gen Pract 2004;54(507):731-3.

19. Gruffydd-Jones K, Ward S, Stonham C, M acfarlane TV, Thomas M. The use of exhaled nitric oxide monitoring in primary care asthma clinics: a pilot study. Prim Care Resp J 2007;16(6):349-56. doi:10.3132/pcrj.2007.00076

20. Chapman KR, Boulet LP, Rea RM, Franssen E. Suboptimal asthma control: prevalence, detection and consequences in general practice. Eur Resp J 2008;31(2):320-5.

21. Levy ML. Guideline-defined asthma control: a challenge for primary care. Eur Resp J 2008;31(2):229-31.

22. Measuring Clinical Outcome in Asthma: A patient focused approach. Pearson MG, Bucknall CE, editors. 7-1-1999. Royal College of Physicians, Clinical Effectiveness \& Evaluation Unit.

23. Gøtzsche PC, Johansen HK, Schmidt LM, Burr ML. House dust mite control measures for asthma (Cochrane Review). In: The Cochrane Library, Issue 4, 2004. London: John Wiley \& Sons Lta.

24. Woodcock A, Forster $L, M$ atthews $E$, et al. Control of exposure to mite allergen and allergen-impermeable bed covers for adults with asthma. N Engl J Med 2003;349:225-36?

25. Marinho S, Simpson A, Custovic A. Allergen avoidance in the secondary and tertiary prevention of allergic diseases: does it work? Prim Care Resp J 2006;15(3):152-8. doi:10.1016/j.pcrj.2006.02.005

26. Health and Safety Executive. Respiratory sensitisers and COSHH. An employers' leaflet on preventing occupational asthma. HSE London 2005.

27. Vandenplas O. Toren K. Blanc PD. Health and socioeconomic impact of work-related asthma. Eur Respir J 2003;22:689-97.

28. Williams LK, Pladevall M, Xi H, et al. Relationship between adherence to inhaled corticosteroids and poor outcomes among adults with asthma. J All Clin Immunol 2004;114:1288-93.

29. Ernst $P$, Spitzer WO, Suissa $S$, et al. Risk of fatal and near-fatal asthma in relation to inhaled corticosteroid use. JAMA 1992;268:3462-4.

30. Suissa S, Elphick HE, Benayoun S, Baltzan M, Cai B. Low-dose inhaled corticosteroids and the prevention of death from asthma. N Eng J Med 2000;343:332-6.

31. Hawkins G, M CM ahon AD, Twaddle S, Wood S, Ford I, Thomson NC. Stepping down inhaled corticosteroids in asthma: randomised controlled trial. BMJ 2003; 326(7399):1115.

32. Hodges IGC, Netherway TA. Once-daily fluticasone propionate is as effective as twice-daily treatment in stable, mild-to-moderate childhood asthma. Clin Drug Invest 2005;25(1):13-22.

33. Szefler S, Rohatagi S, Williams J, Lloyd M, Kundu S, Banerji D. Ciclesonide, a novel inhaled steroid, does not affect hypothalamic- pituitary-adrenal axis function in patients with moderate-to-severe persistent asthma. Chest 2005;128(3):1104-14.

34. Foresi A, Morelli MC, Catena E. Low-dose budesonide with the addition of an increased dose during exacerbations is effective in long-term asthma control. On behalf of the Italian Study Group. Chest 2000;117(2):440-6.

35. Salmeterol (Serevent) and formoterol (Oxis) in asthma management. Curr Probl Pharmacovigilance 2003;29:5.

36. Nelson HS, Weiss ST, Bleeker ER, et al. The salmeterol multi-center asthma research trial: a comparison of usual pharmacotherapy for asthma or usual pharmacotherapy plus salmeterol. Chest 2006;129:15-26.

37. Nelson HS. LABAs in adult asthma: evidence that these drugs are safe. Prim Care Resp J 2006;15(5):271-7. doi:10.1016/j.pcrj.2006.08.006

38. Bateman E, Boushey HA, Bousquet J, et al. Can guideline-defined asthma control be 
achieved? The Gaining Optimal Asthma controL study. Am J Resp Crit Care Med 2004;170(8):836-44.

39. Woodcock AA, Bagdonas A, Boonsawat W, et al. Improvement in asthma endpoints when aiming for total asthma control: salmeterol/fluticasone propionate versus fluticasone propionate alone. Prim Care Resp J 2007;16(3):155-61. doi:10.3132/pcrj.2007.00043

40. Rabe KF, Atienza T, Magyar P, Larsson P, Jorup C, Lalloo UG. Effect of budesonide in combination with formoterol for reliever therapy in asthma exacerbations: a randomised controlled, double-blind study. Lancet 2006;368(9537):744-53.

41. Bousquet J, Boulet LP, Peters MJ, et al. Budesonide/formoterol for maintenance and relief in uncontrolled asthma vs high-dose salmeterol/fluticasone. Respir M ed 2007; 101(12):2437-46.

42. Price $D$, Wirren $A$, Kuna P. Cost-effectiveness of budesonide/formoterol for maintenance and reliever therapy. Allergy 2007;62:1189-98.

43. Ring N, Malcolm C, Wyke S. Promoting the use of Personalised Asthma Action Plans: a systematic review. Prim Care Resp J 2007;16(5):271-83. doi:10.3132/ pcrj.2007.00049

44. Sudre P, Jacquemet S, Uldry C, Perneger TV. Objectives, methods and content of patient education programmes for adults with asthma: systematic review of studies published between 1979 and 1998. Thorax 1999;54(8):681-7.

45. Gibson PG, Powell H. Written action plans for asthma: an evidence based review of the key components. Thorax 2004;59(2):94-9.

46. Toelle BG, Ram FS. Written individualised management plans for asthma in children and adults (Cochrane Review). In: The Cochrane Library, Issue 2, 2004. London: John Wiley \& Sons Ltd.

47. Osman LM, Calder C, Godden DJ, et al. A randomised trial of self-management planning for adult patients admitted to hospital with acute asthma. Thorax 2002;57(10):869-74.

48. Chung KF, Godard P, Adelroth E, et al. Difficult/therapy-resistant asthma: The need for an integrated approach to define clinical phenotypes, evaluate risk factors, understand pathophysiology and find novel therapies. Eur Resp J 1999;13(5):1198208.

49. Prys-Picard CO, Campbell SM, Ayres JG, Miles JF, Niven RM, Consensuls on Difficult Asthma Consortium UK. Defining and investigating difficult asthma: developing quality indicators. Resp Med 2006;100(7):1254-61.

50. Cooper S, Oborne J, Newton S, et al. Effect of two breathing exercises (Buteyko and pranayama) in asthma: a randomised controlled trial. Thorax 2003,58(8):674-9.

51. Netuveli G, Hurwitz B, Levy M, et al. Ethnic variations in asthma epidemiology, morbidity and health service utilisation: systematic review and meta-analysis of epidemiological studies. Lancet 2005;364:312-17.

52. Pulimood TB, Corden JM, Bryden C, Sharples L, Nasser SM. Epidemic asthma and the role of the fungal mold Alternaria alternata. J Allergy Clin Immunol 2007;120:61017.

53. O'Hollaren MT, Yunginger JW, Offord KP, et al. Exposure to an aeroallergen as a possible precipitating factor in respiratory arrest in young patients with asthma. $\mathrm{N}$ Engl J Med 1991;324:359-63.

54. Mohan G, Harrison BD, Badminton RM, Mildenhall S, Wareham NJ. A confidential enquiry into deaths caused by asthma in an English health region: implications for general practice. Br J Gen Pract 1996;46(410):529-32.

55. Harrison BDW, Slack R, Berrill WT, Burr ML, Stableforth DE, Wright SC. Results of a national confidential enquiry into asthma deaths. Asthma J 2000;5(4):180-6.

56. Suissa $S$, Blais L, Ernst P. Patterns of increasing beta-agonist use and the risk of fatal or near-fatal asthma. Eur Respir J 1994;7(9):1602-09.

57. Harrison B, Stephenson P, Mohan G, Nasser S. An ongoing Confidential Enquiry into asthma deaths in the Eastern Region of the UK, 2001-2003. Prim Care Resp J 2005;14(6):303-13. doi:10.1016/j.pcrj.2005.08.004

58. Pearson MG, Ryland I, Harrison BD. Comparison of the process of care of acute severe asthma in adults admitted to hospital before and $1 \mathrm{yr}$ after the publication of national guidelines. Respir Med 1996;90(9):539-45.

59. Geelhoed GC, Landau LI, Le Seouf PN. Evaluation of SaO2 as a predictor of outcome in 280 children presenting with acute asthma. Ann Emerg Med 1994;23(6):1236-41.

60. Wright RO, Santucci KA, Jay GD, Steele DW. Evaluation of pre- and post- treatment pulse oximetry in acute childhood asthma. Acad Emerg Med 1997;4(2):114-17.

61. Cydulka RK, Emerman CL, Schreiber D, Molander KH, Woodruff PG, Carmargo CA Jr. Acute asthma among pregnant women presenting to the emergency department. Am J Respir Crit Care Med 1999;160(3):887-92.

62. Stenius-Aarniala BS, Hedman J, Terano KA. Acute asthma during pregnancy. Thorax 1996;51(4):411-14.

63. O'Driscoll BR, Howard LS, Davison AG, on behalf of the British Thoracic Society Emergency Oxygen Guideline Development Group. Guideline for emergency oxygen use in adult patients. Thorax 2008;63(suppl VI):vi1-vi68.

64. Cates $\mathrm{CJ}$, Rowe BH, Bara A, Crilly JA. Holding chambers versus nebulisers for betaagonist treatment of acute asthma (Cochrane Review). In: The Cochrane Library, Issue 3, 2001. London: John Wiley \& Sons Ltd.

65. Schuh S, Johnson D, Stephens D, Callahan S, Canny G. Hospitalization patterns in severe acute asthma in children. Pediatr Pulmonol 1997;23(3):184-92.

66. Rowe BH, Spooner CH, Ducharme FM, Bretzlaff JA, Bota GW. Corticosteroids for preventing relapse following acute exacerbations of asthma (Cochrane Review). In: The Cochrane Library, Issue 3, 2001. London: John Wiley \& Sons Ltd.

67. Hatton M Q, Vathenen AS, Allen MJ, Davies S, Cooke NJ. A comparison of 'abruptly stopping' with 'tailing off' oral corticosteroids in acute asthma. Respir Med 1995;89(2):101-04.

68. Jamtvedt G, Young JM, Kristoffersen DT, O'Brien MA, Oxman AD. Audit and feedback: effects on professional practice and health care outcomes. Cochrane Database of Systematic Reviews 2006, Issue 2. Art. No.: CD000259. DOI: 10.1002/14651858.CD000259.pub2

69. Haughney J, Small I, Davison H, Kohli HS. Standards for children with asthma in Scotland. Prim Care Resp J 2007;16(4):205-06. doi:10.3132/pcrj.2007.00057

70. Thomas M, Leather D, Price D. High-dose inhaled corticosteroids and add-on therapy use in adults with asthma in the UK in 2003: an observational study. Prim Care Resp J 2006;15:166-72. doi:10.1016/j.pcrj.2006.02.009

71. Thomas M, Turner S, Leather D, Price D. High-dose inhaled corticosteroid use in childhood asthma: an observational study of GP prescribing. $\mathrm{Br} J \mathrm{Gen}$ Pract 2006;56:788-90.

72. Neville R, O'Byrne G, Clark RC, Hoskins G, Smith B for GPIAG. National asthma attack audit 1991-2. BMJ 1993;306:559-62.

73. Pinnock H, Hoskins G, Smith B, Weller T, Price D. A pilot study to assess the feasibility and acceptability of undertaking acute asthma professional development in three different UK primary care settings. Prim Care Resp J 2003;12:7-11.

74. Foster J, Hoskins G, Smith B, Lee AJ, Price D, Pinnock H. Practice development plans to improve the primary care management of acute asthma: randomised controlled trial. BMC Family Practice 2007;8:23.

75. NHS Confederation, British Medical Association. Quality and Outcomes Framew ork guidance for GMS contract 2008/09. Delivering investment in general practice. London, 2008

76. Wiener-Ogilvie S, Pinnock H, Huby G, Sheikh A, Partridge M R, Gillies J. Do practices comply with key recommendations of the British Asthma Guideline? If not, why not? Prim Care Resp J 2007;16(6):369-77. doi:10.3132/pcrj.2007.00074 


\section{PDP/CME questions}

True or false?

Answers are at the bottom of the page.

Diagnosis of asthma in adults and children

A. A definitive diagnosis of asthma can be confirmed solely by:

1. The history

2. Examination

3. Peak Flow variability

4. Spirometry

5. All of the above

B. A high probability of asthma in adults is indicated by the presence of:

1. Wheeze and cough

2. H/O atopic disorder

3. Unexplained low $\mathrm{FEV}_{1}$ or PEF readings

4. History of smoking

5. Unexplained peripheral blood eosinophilia

C. True or false?

1. Occupational asthma is probable if someone gets respiratory symptoms when away from work

2. A child with intermediate probability of asthma may be treated with inhaled bronchodilators on a prn basis

3. In the presence of a suggestive history of asthma, the diagnosis is likely if the PEF variability is over $8 \%$ in the case of two readings a day

4. The Asthma Control Test is a validated test of asthma severity

5. Boys are more likely to grow out of wheezing during adolescence than girls

\section{Non-pharmacological management}

D. The following are useful to exclude an occupational causé for your patients' asthma:

1. A job as a nurse

2. No symptoms while at work.

3. Normal spirometry

4. No variability on PEF charting.

E. The following can help reduce or prevent asthma symptoms:

1. Weight reduction

2. Supplementing dietary anti-oxidants.

3. Breast feeding for four months

4. Reducing house dust mite concentrations.

\section{Pharmacological management of chronic asthma in adults}

F. True or false?

1. The aim of asthma management is to obtain 'high' or 'total' control with no symptoms and no need for rescue medication

2. Stepping up treatment is considerably more important than stepping down

3. Patients at Step 1, using their SABA inhaler for prn use, should be started on ICS if they are using their SABA 1$2 x /$ day

4. The starting dose for ICS treatment is between $800-1000 \mathrm{mcg} /$ day (CFC-containing beclometasone equivalent)

5. There is little evidence of clinically important local or systemic side effects (except dysphonia and candidiasis) from ICS at doses of $<800 \mathrm{mcg} /$ day (CFC-beclometasone equivalent)
G. True or false?

1. The add-on treatment of choice at Step 3 is theophylline

2. It is safe to use LABA inhalers as sole therapy for the treatment of asthma

3. The main advantage of ICS/LABA combination inhalers is that the patient receives a dose of ICS as well as the LABA and can't receive any LABA on its own

4. The SMART regime with the combination budesonide/ formoterol inhaler is licensed for use in patients aged 12 years and over

5. Research has shown that significantly more patients obtained total control with a salmeterol/fluticasone combination inhaler compared to using fluticasone alone.

\section{Pharmacological management of chronic asthma in children}

H. True or false?

1. A child using their SABA five times a week has good asthma control

2. An exacerbation of asthma in the past 2 years is a sign of poor control

3. When reviewing a child who shows poor control of asthma on SABA, ICS should be added straight away

4. Potential side effects should be considered in children taking more than $400 \mathrm{mcg}$ of ICS

I. True or false?

1. All children on $800 \mathrm{mcg}$ of ICS or more should hold a steroid side effect card

2. LTRAs should be the first choice of preventer therapy in children with both asthma and allergic rhinitis

3. $400 \mathrm{mcg}$ of generic CFC-containing BDP is the gold standard treatment for children with asthma

Very small children need higher doses of ICS to control their symptoms

\section{Asthma action plans and self management}

J. True or false?

1. All patients should be given a written personalised asthma action asthma plan?

2. Personalised action plans should include information on:

a. When and how to increase medication

b. When to commence a reserve emergency course of oral steroids

c. When to seek emergency help

3. Assessment of PEF should be based on the personal best PEF value within the last five years

\section{Difficult asthma, asthma exacerbations, and acute asthma}

K. True or false?

1. The term 'Difficult asthma' refers to all patients at step 3 and above

2. Management of acute asthma includes maintaining oxygen saturations of $90 \%$

3. In pregnancy the management of an acute exacerbation of asthma is the same as for a non pregnant women

4. A pMDI and spacer is as effective as using a nebuliser for the administration of $\beta_{2}$-agonist for the management of an acute exacerbation of asthma ә2|6月

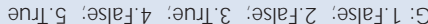

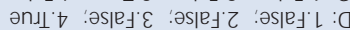

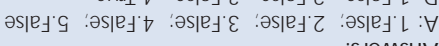

